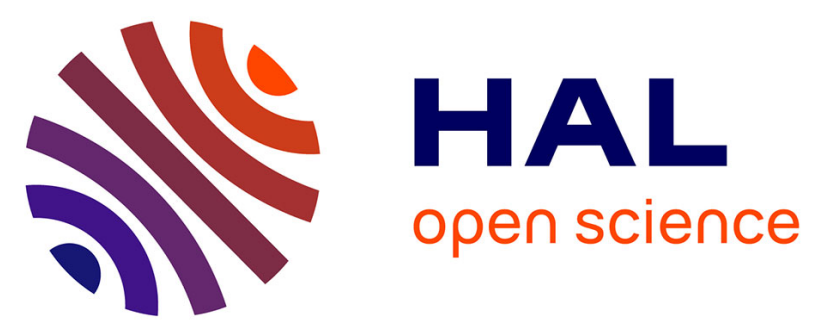

\title{
Cryptogein, a fungal elicitor, remodels the phenylpropanoid metabolism of tobacco cell suspension cultures in a calcium-dependent manner.
}

Nicolas Amelot, Audrey Carrouche, Saïda Danoun, Stéphane Bourque, Jacques Haiech, Alain Pugin, Raoul Ranjeva, Jacqueline Grima Pettenati,

Christian Mazars, Christian Brière

\section{To cite this version:}

Nicolas Amelot, Audrey Carrouche, Saïda Danoun, Stéphane Bourque, Jacques Haiech, et al.. Cryptogein, a fungal elicitor, remodels the phenylpropanoid metabolism of tobacco cell suspension cultures in a calcium-dependent manner.. Plant, Cell and Environment, 2011, 34 (1), pp.149-161. 10.1111/j.13653040.2010.02233.x . hal-00532805

\section{HAL Id: hal-00532805 https://hal.science/hal-00532805}

Submitted on 4 Nov 2010

HAL is a multi-disciplinary open access archive for the deposit and dissemination of scientific research documents, whether they are published or not. The documents may come from teaching and research institutions in France or abroad, or from public or private research centers.
L'archive ouverte pluridisciplinaire $\mathbf{H A L}$, est destinée au dépôt et à la diffusion de documents scientifiques de niveau recherche, publiés ou non, émanant des établissements d'enseignement et de recherche français ou étrangers, des laboratoires publics ou privés. 
4

5 Nicolas Amelot ${ }^{1}$, Audrey Carrouché ${ }^{1}$, Saïda Danoun ${ }^{1}$, Stéphane Bourque ${ }^{3}$, Jacques Haiech ${ }^{4}$, 6 Alain Pugin ${ }^{3}$, Raoul Ranjeva ${ }^{2}$, Jacqueline Grima-Pettenati ${ }^{2}$, Christian Mazars ${ }^{2}$, Christian 7 Brière $^{2}$.

$8 \quad{ }^{1}$ Université de Toulouse; UPS ; UMR 5546, Surfaces Cellulaires et Signalisation chez les $9 \quad$ Végétaux ; BP 42617, F-31326, Castanet-Tolosan, France

Cryptogein, a fungal elicitor, remodels the phenylpropanoid metabolism of tobacco cell suspension cultures in a calcium-dependent manner.

Running title: $\mathrm{Ca}^{2+}$-dependent remodelling of phenylpropanoid metabolism

\section{${ }^{2}$ CNRS ; UMR 5546 ; BP 42617, F-31326, Castanet-Tolosan, France}

${ }^{3}$ UMR INRA 1088 / CNRS 5184 / Université de Bourgogne Plante-Microbe-Environnement, 17 Rue Sully, BP 86510, 21065 Dijon cédex, France;

${ }^{4}$ UMR CNRS 7200, Université de Strasbourg, Faculté de Pharmacie 74, route du Rhin, F67401 Illkirch, France

Author for correspondence:

C. Brière

Pôle de Biotechnologie végétale, UMR 5546 ; BP 42617, F-31326, Castanet-Tolosan, France Tel: +33(0)534323890

email: briere@scsv.ups-tlse.fr 


\section{ABSTRACT}

2 Plant cells use calcium-based signalling pathways to transduce biotic and /or abiotic stimuli

3 into adaptive responses. However, little is known about the coupling between calcium

4 signalling, transcriptional regulation and the downstream biochemical processes. To

5 understand these relationships better, we challenged tobacco BY-2 cells with cryptogein and

6 evaluated how calcium transients (monitored through the calcium sensor aequorin) impact (i)

7 transcript levels of phenylpropanoid genes (assessed by RT-qPCR) and (ii) derived-phenolic

8 compounds (analysed by mass spectrometry). Most genes of the phenylpropanoid pathway

9 were up-regulated by cryptogein and cell wall bound phenolic compounds accumulated

(mainly 5-hydroxyferulic acid). Accumulation of both transcripts and phenolics was calcium-

11 dependent. The transcriptional regulation of phenylpropanoid genes was correlated in a non-

12 linear manner with stimulus intensity and with components of the cryptogein-induced calcium

13 signature. In addition, calmodulin inhibitors increased the sensitivity of cells to low concentrations of cryptogein. These results led us to propose a model of coupling between the cryptogein signal, calcium signalling and the transcriptional response, exerting control of

17 effects. 
1 Keywords: calcium signalling, transcription regulation, phenylpropanoid, modelling,

2 Nicotiana tabacum (tobacco BY-2), cryptogein

\section{Abbreviations}

4 PAL, phenylalanine ammonia-lyase; $\mathrm{C} 4 \mathrm{H}$, cinnamate 4-hydroxylase; 4CL, 4-coumarate-CoA

5 ligase; $\mathrm{C} 3 \mathrm{H}$, p-coumarate 3-hydroxylase; HCT, hydroxycinnamoyl CoA:quinate/shikimate 6 hydroxycinnamoyltransferase; CCoAOMT, caffeoyl CoA 3-O-methyltransferase; COMT

7 caffeic acid/5-hydroxyferulic acid $O$-methyltransferase; F5H, ferulate 5-hydroxylase; CCR, 8 cinnamoyl CoA reductase; CAD, cinnamylalcohol dehydrogenase.

9 
1

2

3

4

\section{INTRODUCTION}

Plant cells use calcium-based signalling pathways to transduce a variety of external and/or internal stimuli into adaptive responses (for review, Hetherington \& Brownlee 2004, Kudla, Batistic \& Hashimoto 2010, Lecourieux, Ranjeva \& Pugin 2006, McAinsh \& Pittman 2009, Sudha \& Ravishankar 2002, White \& Broadley 2003). A paradigm establishing the central role of calcium in a complex regulatory network with multiple interacting components has been inferred, at the single cell level, from the multifaceted approach used to study guard-cell physiology (Allen et al. 2001a, Allen \& Schroeder 2001b, Israelsson et al. 2006, Schroeder et al. 2001). As a general feature, in response to variations of abiotic (light, temperature, drought, etc.) and/or biotic (symbionts, pathogens, etc.) environment including stressful conditions that plants have to face, free calcium concentration varies in cells (Lecourieux $e t$ al. 2002, Pauly et al. 2000, Ward, Pei \& Schroeder 1995, Xiong et al. 2007). These changes control basic cellular functions including ion and molecule transport and most probably gene expression (Kaplan et al. 2006, Kim \& Kim 2006, Lecourieux et al. 2002, Moscatiello et al. 2006). Indeed, the identification of transcriptional regulators modulated by calcium and calmodulin (Kim et al. 2009) supports the importance of calcium in the transcriptional process during plant responses to endogenous and exogenous stimuli.

Also interesting, is the evidence that the calcium signature itself and some of its components (e.g. amplitude, duration) are correlated to gene expression. For instance, during the establishment of symbiosis in root hairs Miwa et al. (2006) showed a correlation between the number of $\mathrm{Ca}^{2+}$ spikes and the transcript level of the Early Nodulation 11 (ENOD11) gene. They suggested that a minimum of 36 spikes is required for ENOD11 induction. Similarly, the shape of the calcium signal in response to salt stress was shown to be very important for the control of salt-stress genes. Using the $\mathrm{Ca}^{2+}-\mathrm{ATPase}$ loss of function mutant in the moss Physcomitrella patens, a sustained elevation of free calcium was observed instead of a 
transient elevation. This sustained level of calcium down-regulates salt-stress-induced genes rendering the mutant plants more susceptible to salt stress (Qudeimat et al. 2008). These examples illustrate how the calcium-dependent processes underlying the calcium signature can control gene expression. It may thus be hypothesized that calcium, as a signal, interferes with the various steps involved in the conversion of a stimulus into a biological output. Surprisingly little is known about the relationships linking calcium to transcriptional regulation, protein synthesis and enzyme activities, and in fine the remodelling of the biochemical processes downstream (Kudla et al., 2010).

For a better understanding of the connections between these different events and to identify critical regulatory steps (Weckwerth 2003) or signalling hubs, we took advantage of the biological model consisting of tobacco cell suspension cultures challenged with cryptogein. Cryptogein, a polypeptide elicitor secreted by the oomycete Phytophthora cryptogea, induces free calcium changes in the cytosol $\left(\Delta\left[\mathrm{Ca}^{2+}\right]_{\text {cyt }}\right)$ in tobacco cells and enhances the transcription of the gene encoding phenylalanine ammonia lyase (PAL), the enzyme catalysing the first committed step of the phenylpropanoid pathway (Lecourieux et al. 2002). Although this biological model has been extensively studied at different levels of the signalling pathway (Garcia-Brügger et al. 2006), it is still not known if other genes of the multi-branched pathway are differentially regulated in response to cryptogein, and there are no data showing changes in enzyme activities or increases in the amounts/concentrations of phenolic compounds.

In the present paper, we made use of this simplified biological system to evaluate qualitative and quantitative changes in successive steps of elicitor-induced signalling pathways, including calcium-transient generation, transcriptional regulation and metabolism reorientation.

Our work aimed at bridging the different steps involved in the signalling pathway that converts the initial perception of cryptogein (input) into the final response (output) that 
consists here of the changes induced in the metabolism of phenolic compounds (Fig. 1). We reasoned that quantitative parameters and time-dependence are essential to get a deeper insight into the regulatory processes and may shed light on overlooked properties. In this way, we have addressed the following questions:

- How do free calcium concentrations vary with time when cells are challenged with increasing concentrations of cryptogein?

- Are all genes coding for the enzymes of the phenylpropanoid pathway induced by cryptogein in a calcium-dependent manner?

- How does cryptogein remodel phenylpropanoid metabolism?

On these grounds we propose an integrated model that could explain key features of the input/output network linking cryptogein signal perception to gene expression through calcium signalling.

\section{MATERIAL AND METHODS}

\section{Products}

Cryptogein was purified according to Bonnet et al. (1996) and dissolved in water as a $100 \mu \mathrm{M}$ stock solution. [ $\left.{ }^{3} \mathrm{H}\right]-\mathrm{S}$-adenosyl-L-methionine (specific activity $0.37 \mathrm{TBq} / \mathrm{mmol}$ ) was from MP Biochemicals (Illkirch, France) and $\left[{ }^{14} \mathrm{C}(\mathrm{U})\right]-\mathrm{L}-$ phenylalanine (specific activity 6.8 GBq/mmol) was from Perkin-Elmer (France). A $5 \mathrm{mM}$ stock solution of native coelentarazine (Interchim, Montluçon, France) in methanol was stored at $-20^{\circ} \mathrm{C}$ in $10 \mu \mathrm{L}$ aliquots. All other compounds were from Sigma-Aldrich.

Radiolabelled trans-cinnamic acid was obtained by the enzymatic conversion of $0.185 \mathrm{MBq}$ of $\left[{ }^{14} \mathrm{C}(\mathrm{U})\right]$-L-phenylalanine by 0.007 units of phenylalanine ammonia lyase (Sigma-Aldrich) in Tris- $\mathrm{HCl}$ buffer $\mathrm{pH} 8.5$ at $30^{\circ} \mathrm{C}$ for 2 hours. After stopping the reaction with $6 \mu \mathrm{L} 6 \mathrm{M} \mathrm{HCl}$, 
Article Amelot.docx

1 cinnamic acid was extracted in $2 \times 1 \mathrm{~mL}$ diethyl ether, evaporated to dryness and taken up in

$250 \mu \mathrm{L} \mathrm{MeOH}$.

\section{Cell culture and luminescence measurements}

4 Transgenic tobacco cells (Nicotiana tabacum L. cv Bright Yellow BY-2 lines) expressing 5 cytosolic apo-aequorin (Takahashi et al. 1997) were grown and processed according to Pauly 6 et al. (2001). Cells harvested at late exponential growth phase were washed twice and 7 resuspended at a density of 20\% (Packed Cell Volume, PCV) in the suspension buffer (175 mM mannitol, $0.5 \mathrm{mM} \mathrm{K}_{2} \mathrm{SO}_{4}, 0.5 \mathrm{mM} \mathrm{CaCl}_{2}, 2 \mathrm{mM}$ MES KOH, pH 5.8), supplemented with $2 \mu \mathrm{M}$ coelenterazine to reconstitute active aequorin for luminescence measurements. Subsequently, cells were incubated at room temperature overnight in the dark on a rotary shaker (130 rpm). Measurements of luminescence and calcium calibration were carried out as previously described (Pauly et al. 2001).

\section{Elicitor treatments}

Cells in suspension medium were transferred into a glass vial and challenged with the indicated concentrations of effectors. After given times of incubation, cell aliquots were collected and filtered under vacuum on a $37 \mu \mathrm{m}$ mesh nylon membrane and immediately frozen in liquid nitrogen.

\section{Quantitative real-time RT-PCR}

Tobacco BY-2 cell samples were ground in liquid nitrogen and total RNAs isolated using the Nucleospin II RNA kit (Macherey-Nagel, Düren, Germany) according to the manufacturer's instructions. First-strand cDNA was synthesized from $5 \mu \mathrm{g}$ total RNA in a $20 \mu 1$ reaction volume containing 50ng random primers, $10 \mathrm{mM}$ dNTPs, $1 \mu \mathrm{l}$ RasOUT (40 units) and 200 units of SuperScript III reverse transcriptase, according to the manufacturer's instructions (Invitrogen, Carlsbad, USA). After 50 minutes at $50^{\circ} \mathrm{C}$ followed by 5 minutes at $85^{\circ} \mathrm{C}$, cDNAs were purified using the PCR Clean-Up system (Promega, Madison, USA). Two $\mu \mathrm{L}$ 
cDNAs were used as templates in a quantitative real-time PCR assay $(10 \mu \mathrm{L})$ performed on the sequence detection system ABI PRISM 7900HT (Applied Biosystems, Foster City, USA) using the SYBR Green PCR Master Mix (Applied Biosystems). After an initial denaturation of 10 minutes at $95^{\circ} \mathrm{C}, 40$ cycles of $15 \mathrm{sec}$ at $95^{\circ} \mathrm{C}$ followed by 1 minute at $60^{\circ} \mathrm{C}$ were performed. Amplification specificity was checked by melting-curve analysis, and PCR efficiency was determined using standard curves constructed with serial dilutions of PCR products as templates. 18S rRNA was used as an internal control. Quantification of expression ratios was performed according to the mathematical model developed by Pfaffl (2001). Primers and amplicon sizes are given in Supporting Information (table S1). In the case of multigene families, primers have been designed to hybridize either to all known genes of the class postulated to have a role in lignin biosynthesis and/or specifically to one gene member (table S1).

\section{Measurement of enzymatic activities of PAL and CCOAOMT}

Cell samples were ground in liquid nitrogen and weighed (approx. $2 \mathrm{~g} / \mathrm{sample}$ ) before being extracted for 30 minutes in $4 \mathrm{~mL}$ of protein extraction buffer $(2 \mathrm{mM} \mathrm{MgCl} 2,10 \mathrm{mM}$ DDT, antiprotease (P9599 Sigma), $10 \%$ glycerol, $0.1 \mathrm{M}$ Tris- $\mathrm{HCl} \mathrm{pH} 7.5$ ) at $4^{\circ} \mathrm{C}$ under gentle shaking. After a 30 minute centrifugation $\left(10000 \mathrm{x} \mathrm{g}, 4^{\circ} \mathrm{C}\right)$ the supernatant was collected and desalted on a PD10 column equilibrated with the same buffer at $\mathrm{pH} 7.5$ for CCoAOMT activity or $\mathrm{pH} 8.8$ for PAL activity measurements. PAL activity was assayed by spectrophotometry. The reaction mixture $(1 \mathrm{~mL})$ contained $50 \mu \mathrm{g}$ protein extract and $1 \mathrm{mM} \mathrm{L}-$ phenylalanine (Sigma) in $0.1 \mathrm{M}$ Tris-HCl, $\mathrm{pH} 8.8$ buffer. The formation of cinnamic acid was monitored for 10 minutes by measuring absorption at $290 \mathrm{nM}$ and PAL activity was determined from the slope of the absorption curve using the extinction coefficient of cinnamic acid at $290 \mathrm{~nm}=10000 \mathrm{M}^{-1} \mathrm{~cm}^{-1}$ 
1 CCOAOMT activity was determined by radiometric assay. The reaction mixture contained

$210 \mu \mathrm{L}$ of protein extract, $3.7 \mathrm{kBq}\left[{ }^{3} \mathrm{H}\right]-\mathrm{S}$-adenosyl-L-methionine, $40 \mu \mathrm{M}$ S-adenosyl-Lmethionine, $40 \mu \mathrm{M}$ caffeoyl-CoA in $0.1 \mathrm{M}$ Tris- $\mathrm{HCl}$, $\mathrm{pH} 7.5$ (total volume $50 \mu \mathrm{L}$ ). After 30 minutes of incubation at $30^{\circ} \mathrm{C}$ the reaction was stopped with $10 \mu \mathrm{l} 3 \mathrm{M} \mathrm{NaOH}$ and incubated for a further 10 minutes at $37^{\circ} \mathrm{C}$ to allow feruloyl-CoA hydrolysis before adding $40 \mu \mathrm{L} 1 \mathrm{M}$ $\mathrm{HCl}$ to stop the reaction. Ferulic acid was extracted 10 minutes in $200 \mu \mathrm{L}$ of hexane/ethyl acetate $(1: 1 \mathrm{v} / \mathrm{v})$ and $150 \mu \mathrm{L}$ of the organic phase was collected and evaporated overnight before addition of $8 \mathrm{~mL}$ of scintillation cocktail for radioactivity counting.

\section{Radioactivity measurements}

$\left[{ }^{14} \mathrm{C}\right]$-cinnamic acid was added to the cells $\left(0.007 \mathrm{MBq} . \mathrm{g}^{-1}\right.$ fresh cells) immediately before treatment with cryptogein. After 4 hours of incubation at $20^{\circ} \mathrm{C}$ in the dark and under shaking, cell aliquots were filtered under vacuum and frozen immediately. A $1 \mathrm{~mL}$ aliquot of filtrate was collected and transferred into a scintillation vial containing $8 \mathrm{~mL}$ of Ready Safe cocktail (Beckman Instr., Fullerton CA USA) to measure residual radioactivity in the medium. Frozen cell samples were weighed before grinding in $80 \%$ EtOH with glass beads (Fastprep system, MP Biomedicals, Illkirch, France). Ground cells were then extracted for 30 minutes at $4^{\circ} \mathrm{C}$ in $5 \mathrm{ml} 80 \% \mathrm{EtOH}$ under gentle shaking, and centrifuged 10 minutes at $3000 \mathrm{x}$ g. A $1 \mathrm{~mL}$ aliquot of supernatant was collected for measuring the radioactivity of ethanol-soluble compounds (total radioactivity). Another $1 \mathrm{~mL}$ aliquot of the supernatant was added to a PVPP column, which selectively complexes phenolic compounds (radioactive soluble phenolics). Radioactive non-phenolic products were recovered in the pass through (radioactive soluble non-phenolics) and the distribution of the radiolabel was calculated as: radioactive soluble phenolics $=$ total radioactivity - radioactive non-phenolics. The remaining supernatant was discarded and the cell pellet resuspended in water, and a $200 \mu \mathrm{L}$ aliquot collected for counting the radioactivity incorporated into the non-soluble fraction. 


\section{Extraction and analysis of soluble and wall-bound phenolics}

2 Frozen cell samples were ground in liquid nitrogen, and the powder weighed before being

extracted in $5 \mathrm{~mL} 80 \% \mathrm{EtOH}$ for 30 minutes at $4{ }^{\circ} \mathrm{C}$ under gentle shaking in the dark. After 10 minute centrifugation at $3000 \mathrm{x} \mathrm{g}$ the supernatant was collected for analysis of soluble phenolics. Phenolic material contained in the ethanol-insoluble fraction was extracted according to Bolwell et al. (1985). The pellets were resuspended in $5 \mathrm{~mL}$ of $4.25 \mathrm{M} \mathrm{NaOH}$ and hydrolyzed for 6 days at $4^{\circ} \mathrm{C}$ followed by 1 day at $37^{\circ} \mathrm{C}$ in the dark under gentle shaking. After 15 minute centrifugation at $4500 \mathrm{x} \mathrm{g}$ the supernatant was collected, acidified to $\mathrm{pH} 1$ with $12 \mathrm{M} \mathrm{HCl}$, then extracted twice in ethyl acetate. The organic phase was collected, and evaporated to dryness under $\mathrm{N}_{2}$. The residue was re-dissolved in $100 \mu \mathrm{L}$ of water/methanol (1/1 v/v) for analysis by UPLC-QTOF using a Waters ACQUITY UPLC System (Waters, Milford MA, USA). Separation was achieved using an ACQUITY UPLC BEH C18 column (100 mm, $2.1 \mathrm{~mm}$ i.d., $1.7 \mu \mathrm{m}$ particle size; Waters) maintained at $40^{\circ} \mathrm{C}$, with a mobile phase flow rate of $0.30 \mathrm{~mL} \cdot \mathrm{min}^{-1}$ in isocratic mode. The mobile phase contained $32 \%$ methanol and $0.1 \%$ formic acid in water. The injection volume was $2 \mu \mathrm{L}$ with partial loop. A time-of-flight mass spectrometer with an electrospray ionization (ESI-MS) interface was used for mass spectrometry analysis (Micromass, Manchester, UK). Data acquisition was performed using negative ion mode over a $\mathrm{m} / \mathrm{z}$ range $50-1000$. The general conditions were: source temperature $130{ }^{\circ} \mathrm{C}$, capillary voltage $-2.8 \mathrm{kV}$ and cone voltage $40 \mathrm{~V}$, extraction cone $-4 \mathrm{~V}$, ion guide $-1 \mathrm{~V}$, the collision energy $5 \mathrm{eV}$, desolvatation temperature $350{ }^{\circ} \mathrm{C}$, desolvatation flow $750 \mathrm{~L} \cdot \mathrm{h}^{-1}$, the nebulizer $30 \mathrm{~L} \cdot \mathrm{h}^{-1}$ and data were acquired using a scan time of $0.5 \mathrm{~s}$. Leucine-enkephalin $(\mathrm{M}-\mathrm{H})^{-}(\mathrm{m} / \mathrm{z}, 554.2615)$ was used for the lock mass of the lock spray. MassLynx 4.1 software (Waters, Manchester, UK) was used for data analysis. 
Article Amelot.docx

1 Phenolic compound identification was based on comparison of retention times of commercial

2 standards, accurate mass measurements, and MS/MS fragmentation analysis (collision energy:

$3 \quad 15 \mathrm{eV})$.

\section{Statistical analysis}

5 Statistical tests and multivariate analysis (Principal Component Analysis) were carried out 6 using the R statistical software (R Development Core Team 2009).

\section{RESULTS}

8 Cryptogein induces a biphasic calcium signature in tobacco BY-2 cells

9 Cryptogein induces biphasic calcium variations in the cytosol of BY2 cells (Fig. 2a). This

response is characterized by an increase of free cytosolic calcium $\Delta\left[\mathrm{Ca}^{2+}\right]_{\text {cyt }}$ starting as early as 2 minutes after elicitation, reaching a maximum after about $5 \mathrm{~min}$, followed by a sustained elevation (plateau) of cytosolic free calcium lasting for more than an hour. This cytosolic calcium variation was inhibited in cells co-incubated with $1 \mathrm{mM} \mathrm{La}^{3+}$, illustrating the absolute requirement of an external calcium influx. The maximum calcium elevation (peak value) and the plateau value increased in a dose-dependent manner but with different $\mathrm{EC}_{50}$ values (Fig. 2b). Thus, the maximum plateau value is reached for very low cryptogein concentrations (less than $100 \mathrm{nM}$ ), while the peak value continues to increase for cryptogein concentrations above $1 \mu \mathrm{M}$. Fitting a simple one-site binding model to experimental data enabled us to estimate the $\mathrm{EC}_{50}$ values at $128 \mathrm{nM}$ cryptogein for the calcium peak $(\mathrm{Bmax}=0.9 \mu \mathrm{M})$ and to $17 \mathrm{nM}$ cryptogein for the calcium plateau $(B \max =0.1 \mu \mathrm{M})$, a value close to the measured $\mathrm{Kd}$ of cryptogein binding to cell membranes (Bourque et al. 1999). This suggests either the existence of two cryptogein receptors, with low and high affinities, and involved in the generation of the calcium-peak or the sustained plateau respectively, or the existence of only 
Article Amelot.docx

1

2

3

4

5

6

one type of cryptogein receptor, but interacting with two types of protein complexes with different affinities.

\section{Cryptogein strongly increased the number of transcripts of genes of the}

\section{common phenylpropanoid biosynthetic pathway}

We measured the transcript levels of genes encoding enzymes involved in the synthesis of phenylpropanoids and lignin $(P A L, C 4 H, 4 C L, H C T, C 3 H, C O M T, C C O A O M T, F 5 H, C C R$ and $C A D$ ), as well as of three genes known to be involved in defence responses: HSR203J, a cell death response marker (Pontier et al. 1994), and two PR genes, PRI and PR3 (Ward et al. 1991). Transcripts levels in tobacco BY-2 cells were measured using RT-qPCR after treatments of cells with various concentrations of cryptogein (from $10 \mathrm{nM}$ to $1 \mu \mathrm{M}$ ) and different durations (from 30 minutes to 8 hours). The ratios of transcripts levels in treated to that in control cells are presented in Fig. 3.

After a cryptogein treatment of $3 \mathrm{hr}$, the transcript levels of the majority of the genes tested were strongly enhanced, but to different extent, ranging from 4-fold for $\mathrm{C} 4 \mathrm{H}$ to about 200fold for CCOAOMT and $F 5 H$. In the core pathway, $P A L, C 4 H$ and $4 C L$ transcript accumulation was increased on average by 26-, 4- and 15-fold respectively. In contrast transcript accumulation of $C A D$, the last gene of the monolignol biosynthesis pathway, was decreased by about 2-fold. Interestingly, cryptogein had no effect on transcription of the two defence marker genes ( $P R I$ and $P R 3)$ while the expression of the cell death response marker HSR203J was strongly up-regulated (55-fold on average).

Transcript accumulation of tested genes was strongly inhibited when cells were challenged with cryptogein in the presence of $1 \mathrm{mM} \mathrm{La}^{3+}$, a calcium channel blocker (Fig. 3a), or in the presence of the calcium chelator EGTA (Supplemental information S2), showing that calcium influx was required for the transcriptional response. 
1 De novo synthesis of proteins was also required to allow the transcriptional response to

cryptogein, as shown by its complete suppression by a 30 minute pre-treatment of the cells with cycloheximide prior to the addition of cryptogein (Supporting Information Fig. S3).

Because many genes of the phenylpropanoid pathway belong to small gene families, we examined transcript accumulation in response to cryptogein for each known isoform of three strongly induced genes. For PAL and 4CL, only the expression of one gene member was upregulated, PAL A and 4CL2, respectively. Transcript levels of CCOAOMT genes were highly and equally up-regulated upon cryptogein treatment except CCOAOMT5 which was only weakly activated in comparison to the other family members (Supporting Information Fig. S4). These data show that the intensity of the transcriptional response within a gene family may be specific either for a particular gene or for a set of genes.

The magnitude of the transcriptional response to cryptogein increased with time and depended upon the intensity of the stimulus. As exemplified with PAL, CCOAOMT and HCT, the transcript levels of the most activated genes increased after the cryptogein treatment as early as 30 minute and continued increasing for several hours (Fig. 3b). Different induction kinetics patterns were observed depending on the gene considered. Transcripts levels of some genes like CCOAOMT reached a maximum after 4 hours of treatment then decreased, while transcripts of other genes like COMT and HSR203J continued to accumulate for 8 hours.

Furthermore, the intensity of the transcriptional response was strongly dependent upon the intensity of the stimulus (Fig. 3c). Similar dose-response curves were observed for the different genes of the phenylpropanoid pathway, showing a strong correlation between these genes in terms of dose dependence. Dose-response curves were non-linear and biphasic: the effect of cryptogein began to be significant at $20 \mathrm{nM}$, reached a maximum between $50 \mathrm{nM}$ and $100 \mathrm{nM}$ (depending on the gene considered), and then decreased fairly sharply while 
1 increasing the cryptogein concentration (Fig. 3c). As observed for the kinetics patterns,

2 differences in the dose-response curves were observed between genes.

3 Thus, in order to analyse the correlations between gene transcript ratios in dose-response experiments, we performed a Principal Component Analysis (PCA) of the correlations between kinetic data obtained for all studied genes. Briefly, this multivariate analysis allows representing graphically the correlations between variables and/or the proximities between observations on planes with a minimal loss of information. "Calcium-peak" and "Calciumplateau" values measured at different concentrations of cryptogein were included in this analysis in order to analyze the correlations between transcript ratios and these two characteristics of the calcium signature. This analysis led to the definition of two groups of up-regulated genes in addition to the group formed by $C A D, P R 1$ and $P R 3$ that are not up- or even down-regulated (Fig. 4). The first group (4CL, C4H,C3H,COMT, F5H, CCR) is correlated with the "Ca-peak" variable and is colocalized with observations made at 100nM, $200 \mathrm{nM}$ and $1 \mu \mathrm{M}$ cryptogein., It corresponds to genes whose transcript accumulation reached a maximum for cryptogein concentrations above $100 \mathrm{nM}$. The second group (PAL, HCT, CCOAOMT, and HSR203J), correlated to the "Ca-plateau" variable, corresponds to genes whose activation was maximal at $60 \mathrm{nM}$ cryptogein and then decreased for higher concentrations.

\section{Cryptogein-induced enhancement of transcription correlates with increased}

\section{activities of enzymes of the phenylpropanoid pathway}

In order to evaluate whether transcriptional activation was correlated with the activation of the corresponding enzymes, we assayed the enzymatic activities of PAL and CCoAOMT whose corresponding genes were among the most activated. These activities were strongly increased (2.5x for PAL, 6x for CCOAOMT) in BY2 cells challenged with $0.1 \mu \mathrm{M}$ cryptogein for 4 
1 hours as compared to control cells (Fig. 5). These increases were totally inhibited when the

2 cells were treated by $1 \mathrm{mM} \mathrm{La}^{3+}$ (Fig. 5 inset). A kinetic study showed that the cryptogein-

3 induced increase of these enzyme activities began as early as 30 minute after elicitation for

4 CCoAOMT (2 hours for PAL) and increased continuously during the whole experiment (8

5 hours). This continuous increase is consistent with the increases in transcript levels of the

6 corresponding genes (Fig. 5), indicating that cryptogein-induced enhancement of transcript

7 accumulation resulted in an increase of enzymatic activities.

\section{Cryptogein induces accumulation of cell-wall associated phenolic compounds}

9 From the results presented above, we reasoned that the distribution of phenolics (metabolic remodelling) might be significantly altered in cells challenged with cryptogein. To address this question, cells were fed with $\left[{ }^{14} \mathrm{C}(\mathrm{U})\right]$-cinnamic acid and incubated with cryptogein. After 4 hours of incubation, the cell suspension was filtered and radioactivity was measured in different fractions: external medium, phenolic soluble fraction, non-phenolic soluble fraction, and insoluble fraction (containing insoluble phenolics). Compared to control cells, cryptogein-treated cells showed a slight decrease of residual radioactivity in the external medium and in the soluble fraction containing non-phenolic compounds (including radiolabelled free cinnamic acid), but an increase in the insoluble fraction (Fig. 6). The variations of radioactivity in the different fractions were inhibited by $1 \mathrm{mM} \mathrm{La}^{3+}$ suggesting that, in line with what we showed for gene expression and enzymatic activities, the putative remodelling of phenolic metabolism is a calcium-dependent process. The decrease of radioactivity observed in the soluble non-phenolic fraction and the concomitant increase measured in the insoluble fraction in response to cryptogein strongly suggest an accumulation of phenolics in the cell walls.

In order to identify these insoluble phenolic compounds, cell wall pellets were hydrolyzed with $\mathrm{NaOH}$ in order to release associated esterified phenolics that were further analyzed by 
1 MS/MS. Intermediate compounds of the "core" phenylpropanoid pathway were found to be

2 significantly increased in cryptogein-treated samples as compared to controls i.e.: $p$-coumaric acid, ferulic acid, and 5-hydroxy-ferulic acid which was found only as traces in control samples but at a high level in cryptogein-treated cells. In addition, a small increase in 4hydroxybenzaldehyde was also observed in treated cells (table 1).

\section{Calcium controls the cryptogein-induced response}

The data reported above are consistent with the existence of non-linear relationships between different steps of cryptogein signalling in tobacco cells and highlight the crucial role of the steps associated with the generation of the calcium signature. They further suggest the possible co-existence of regulatory modules differing in their sensitivity to calcium and/or effector concentration, and able to modulate the response at the transcriptional level. These results raise questions on the respective roles of the two phases of the cryptogein-induced calcium signature and on the potential involvement of calcium sensor proteins.

To address these questions, we disturbed the cryptogein-induced response either by modulating the calcium response at a key step of the time course, or by using inhibitors of calcium-sensor proteins and we further investigated the effects of these perturbations on the transcript levels of representative genes.

\section{Sustained calcium elevation plays a key role in the cryptogein-induced response}

In order to determine the relative importance of the transient peak and of the sustained phase of calcium elevation (plateau) in cryptogein-induced transcriptional regulation, we applied $1 \mathrm{mM} \mathrm{La}^{3+}$ either just before the cryptogein treatment, thus suppressing the whole calcium response (light grey curve, Fig. 7a), or 10 minutes after cryptogein treatment (arrow) in order to maintain the first peak while suppressing the sustained plateau (dark grey curve, Fig. 7a). After a 3-hour treatment, we measured the accumulated level of transcripts of phenylpropanoid genes in each condition (Fig. 7b). 
Adding lanthanum just before or 10 minutes after the cryptogein treatment resulted in both cases in a strong reduction of transcript levels of PAL, HCT or CCOAOMT (Fig. 7b) as compared to cryptogein treatment alone (see also Fig 3a). Furthermore no significant difference $(p=0.05)$ was observed between the inhibitory effects of the two treatments with lanthanum. In contrast, cryptogein-induced accumulation of transcripts of $C 4 H, 4 C L, C 3 H$, COMT and CCR was only slightly modified by addition of lanthanum after 10 min, suggesting that transcriptional regulation of these genes is mainly dependent of the early calcium influx. It is noteworthy that these two subsets of genes are identical to those identified by the PCA analysis, suggesting a possible link between the intensity of the stimulus (PCA analysis; figure 4), the two different phases of the calcium response (figure 7) and gene expression.

\section{Regulators with low and high affinity for calcium control the transcriptional response}

To assess the possibility of regulatory effects downstream of the calcium signal, we evaluated the effects of compounds able to interact with calmodulins or CaM-like proteins on cryptogein-induced responses. We used W-13 known as a calmodulin inhibitor $(\mathrm{Kd}=50 \mu \mathrm{M})$ and W-12 (a molecule of the same family as $\mathrm{W}-13$ with a $\mathrm{H} / \mathrm{Cl}$ substitution and a lower affinity for $\mathrm{CaM}, \mathrm{Kd}=250 \mu \mathrm{M})$ as negative control.

By themselves, these drugs provoked changes in cellular calcium (Dagher et al. 2008) but in a differential manner (Supporting Information Fig. S4). Within two minutes, the calmodulin inhibitor W-13 induced a transient dose-dependent increase in cytosolic calcium, followed by a rapid decrease to the resting level. In contrast, W-12 here considered as the negative counterpart of W-13, induced significantly lower calcium variations in the cytosol. In subsequent experiments these two compounds were used at a final concentration of $50 \mu \mathrm{M}$ for which the calcium level returned to the basal level within 10 minutes. In order to investigate the effect of these two drugs either on the calcium response or on the transcriptional response 
1

induced by cryptogein, $\mathrm{W}-13$ or $\mathrm{W}-12$ were added to the cell suspension 10 minutes before cryptogein treatment. Then, cytosolic calcium variations were recorded for $15 \mathrm{~min}$, and the cells were collected after 4 hours for transcriptional analysis. The calcium response induced by high concentrations of cryptogein $(0.25 \mu \mathrm{M}$ and above) was not modified by either inhibitor, but when cryptogein was added at low concentrations $(<50 \mathrm{nM})$ the sustained calcium elevation (plateau value), and to a lesser extent the peak value, were significantly increased by W13 (Fig. 8a), but not by W12 (not shown). When added alone, these compounds had no effect on the transcript level of phenylpropanoid genes (not shown). When added before cryptogein-treatment, they had no effect on the transcript increase induced by concentrations of cryptogein above $100 \mathrm{nM}$, but a strong enhancement of the cryptogein effect was mediated by the CaM inhibitors at low concentrations of cryptogein i.e. $25 \mathrm{nM}$ (Fig. 8b). As expected, this effect was higher with the calmodulin inhibitor W-13 than with its negative counterpart W-12.

These results confirm the importance of the plateau phase of the calcium signature in the increase of transcript levels induced by cryptogein. Furthermore, the differential effect of antiCaM compounds, between low and high cryptogein treatments, is consistent with the hypothesis that two calcium decoding modules, one with low affinity and the other with high affinity for calcium, are involved in the regulation of this response.

\section{Modelling the coupling between cryptogein-induced calcium and}

\section{transcriptional responses}

The results presented above show the existence of correlations between the different phases of the cryptogein-induced calcium signature and the transcriptional response: the calciumplateau value correlates positively with transcript accumulation, while an increase of the calcium-peak value above a threshold correlates negatively with transcript accumulation. Furthermore they support the hypothesis of two decoding modules (involving different 
1

calcium sensors) able to modulate the response to cryptogein and which could explain the observed correlations.

To test this hypothesis and verify its coherence with the experimental data we used computer modelling and built a model of the non-linear system coupling the cryptogein signal to calcium and transcriptional regulation. The model can be described as follows (see scheme Fig. 9).

Perception of cryptogein triggers opening of calcium channels, which results in an influx of external calcium. This calcium influx activates calcium-dependent mechanisms that depends upon the strength of the stimulus (= cryptogein concentration). At low concentrations of cryptogein $(10 \mathrm{nM}-50 \mathrm{nM})$, the concerted activation of calcium channels and transporters results in a small but sustained elevation of free cytosolic calcium concentration (=plateau value). This increase (or influx) is nevertheless sufficient to activate calcium-sensors belonging to a high affinity decoding module (module 1), which in turn will enhance transcription of response genes. For higher cryptogein concentrations $(>50 \mathrm{nM})$, the larger calcium influx triggers the release of calcium from internal stores and/or the opening of additional plasma-membrane calcium channels, resulting in a large transient increase of cytosolic calcium (=peak value) followed by a slow return to the plateau value through the action of homeostatic mechanisms. This has two consequences: 1) the activation of high affinity module 1 due to sustained calcium elevation, and thus differential expression of responsive genes, and 2) the activation of other calcium responsive effectors of a low-affinity module (module 2), which have an inhibitory effect on the transcription of the same genes. This results in equilibrium between activation-inhibition mechanisms through the activation of these two modules, linking the transcriptional response to the cryptogein concentration in a non-linear manner. 
1 We used a simple phenomenological approach to formalize this model using a twocomponent system derived from chemical binding kinetics (Supporting Information S7). In this model each component (modules 1 and 2) is characterized by an "apparent" affinity constant for cryptogein (K1 and K2 resp.), a parameter defining its maximum activity (S1 and S2 resp.), and a Hill coefficient (n1 and n2 resp.) to account for cooperativity. This model integrates, in a simple way, all the steps between cryptogein binding and transcriptional activation, and thus its parameters depend implicitly on the characteristics of the calcium decoding modules. This model fits well to experimental dose-response curves obtained for transcription of $P A L, H C T$, and CCOAOMT (Fig.10a). Interestingly, the $\mathrm{K}$ values for cryptogein estimated for each component were both very close to the $\mathrm{Km}$ value of the doseresponse curve observed for the calcium plateau $(30 \mathrm{nM})$, which is in the range of $\mathrm{IC}_{50}$ values measured for cryptogein binding to its receptor. In order to test the model further, we used it to fit the effect of calmodulin inhibitors on cryptogein-induced transcription. A good fit to experimental curves was obtained (Fig.10b) by increasing the affinity parameter K1 that corresponds to the "apparent" affinity of the "activation" module (the other parameters being held constant). Interestingly, the K1 value estimated for the W13 experimental curve was greater than its value estimated for W12.

The hypothetical mechanisms at the basis of this simple model seem to be sufficient not only to fit dose-response curves but also the effect of anti-calmodulin compounds on the transcriptional response to cryptogein. It is worth noting that this model was built on assumptions derived from observed correlations between calcium and expression data only. However, by modifying only two parameter values, the model was able to simulate (at least qualitatively) the effect of anti-calmodulin compounds. Considering that data from anti-CaM experiments were not used to derive the model, this last result is in some extent a first step in the validation of this model. 


\section{DISCUSSION}

3 In this work our aim was to build an integrated view of the relationships linking the calcium response to the short-term responses induced at the transcriptional and metabolic levels by the necrotizing elicitor cryptogein in BY-2 cells. For this purpose, we first carried out a quantitative analysis of the biological responses at different levels, and then exploited these data to propose a simple coupling model between calcium variations and transcriptional regulation of genes of the phenylpropanoid pathway.

\section{Cryptogein increases transcription of most genes of the phenylpropanoid}

\section{pathway}

In BY-2 cells cryptogein induced an increase of transcript levels for most of the genes of the phenylpropanoid pathway, with expression ratios ranging from 4 (e.g. $C 4 H$ ) to more than 100 (e.g. $C C O A O M T$ ), but with the noticeable exception of $C A D$, which catalyses the last step leading to lignin monomers, that was not induced or was even repressed for high concentrations of elicitor. These transcriptional responses occurred early after elicitation (less than 30 minutes for the most activated gene CCoAOMT) and transcript accumulation continued increasing for several hours, reaching a maximum after 4 hours for $P A L, H C T$ and CCOAOMT. For other activated phenylpropanoid genes like COMT, their transcripts continued to accumulate for at least 8 hours after treatment. Depending on the gene, these responses were totally or partially, suppressed when calcium influx was blocked by lanthanum. This is consistent with the calcium-dependence of the biological responses to cryptogein shown in previous works (Lecourieux et al. 2002).

An increased accumulation of transcripts of genes coding for key enzymes of the phenylpropanoid pathway (PAL, 4CL, CCoAOMT, C4H) in response to elicitors has been previously reported in various plant species (Dixon \& Paiva 1995, Hano et al. 2006, Kauss et 
al. 1993, Shinya et al. 2007, Suzuki et al. 2003). In particular, cryptogein activates transcription of the phenylalanine-ammonia lyase (PAL) gene in tobacco cells (Lecourieux et al. 2002, Suty et al. 1995). In this work, we extended the study to a larger set of genes belonging to the phenylpropanoid pathway and quantified corresponding transcript levels.

Transcription of HSR203J, a marker of hypersensitive response in tobacco (Pontier et al. 1994), was strongly increased by the cryptogein treatment as previously shown (Lecourieux et al. 2002). In contrast $P R I$ and $P R 3$, two genes involved in defence responses through the salicylic acid pathway (Keller et al. 1996a, Ward et al. 1991), were not differentially expressed in BY-2 cells. This is in agreement with the known biological effect of cryptogein in tobacco, which induces cell death through a hypersensitive response, while the salicylic pathway has been shown not to be involved in the HR response (Keller et al., 1996).

\section{Phenolic metabolism changes in response to cryptogein}

In tobacco BY-2 cells, cryptogein induced an early accumulation of cell-wall bound phenolic compounds ( $p$-coumaric acid, ferulic acid, 5-hydroxyferulic acid, 4-hydroxybenzaldehyde), whereas no consistent variation of free soluble phenolics was detected after a 4-hour treatment. The accumulation of cell-wall-bound phenylpropanoid derivatives has often been described as a form of biochemical defence in response to elicitors. For instance, Bolwell et al. (1985) reported an accumulation of phenolic material bound to cellulosic and hemicellulosic fractions and of free hydroxycinnamic acids in bean cells. Some of the phenolicbound esters identified in this study were also found in cells treated with elicitor fractions from other oomycetes. It is the case of extracts from Phytophthora megasperma that induced accumulation of cell-wall-bound 4-coumaric acid, ferulic acid, 4-hydroxybenzoic acid, 4hydroxybenzaldehyde and vanillin (Kauss et al. 1993). Cell-wall-bound 4hydroxybenzaldehyde and tyramine amides were also detected in suspension cultures of potato treated with an elicitor extract of Phytosphora infestans (Keller et al. 1996b). 
1 Since in response to cryptogein, CAD transcript levels are slightly down-regulated whereas

2 most upstream genes are up-regulated, it is conceivable that the CAD substrate

3 (coniferaldehyde) could be (at least in part) not converted into coniferyl alcohol, but rather

4 redirected to ferulic acid by oxidation. Such a hydroxycinnamaldehyde dehydrogenase

5 (REF1, AtALDH2C4) activity has been demonstrated in Arabidopsis thaliana (Nair et al.

6 2004). The identification of this enzyme inverted the conventional model of flux, ferulate and

7 sinapate being products of coniferaldehyde and sinapaldehyde oxidation, rather than being precursors in their synthesis. In support of the hypothesis that cell-wall-bound ferulate could originate from coniferaldehyde, we recently identified within the publicly available tobacco

ESTs, a sequence highly homologous to AtALDH2C4. Furthermore, we have shown that this gene was significantly over-expressed by 5 times in BY-2 cells challenged with cryptogein (Amelot et al, in preparation).

An increased amount of 4-hydroxybenzaldehyde was also observed in cryptogein-treated cells. Although the origin of this compound is unknown, one could hypothesize the existence of a 4-hydroxybenzaldehyde synthase activity in tobacco. Such a synthase activity, which converts 4-coumaric acid to hydroxybenzaldehyde, was found in tissue cultures of Vanilla planifolia (Podstolski et al. 2002) and in hairy root cultures of Daucus carota (Sircar \& Mitra 2008).

Taken together, our results clearly show a reorientation of the phenylpropanoid metabolism in response to cryptogein, resulting in the incorporation of new cell wall phenolic compounds which likely reinforce the cell wall barrier. Moreover they suggest a new possible route accounting for the accumulation of ferulic acid in tobacco BY-2 cells.

\section{Calcium controls the cryptogein-induced responses}

Our results showed that the phenylpropanoid genes belong to two distinct subsets that respond differentially to cryptogein treatment. The regulation of these two subsets differs by their 
sensitivity to stimulus intensity (i.e. cryptogein concentration) as well as by their correlation with one particular phase of the calcium signature (peak and/or plateau). Indeed, the long lasting influx of calcium responsible for the sustained increased level of cytosolic calcium (plateau) is necessary for the appropriate transcriptional response of genes induced by low concentrations of cryptogein (i.e. PAL, HCT and CCOAOMT). Thus, a positive correlation is observed at low cryptogein concentrations between the sustained calcium elevation and transcript accumulation of these genes, while at higher concentrations the calcium peak value was negatively correlated with transcription. On the other hand, $C 4 H, 4 C L, C 3 H, C O M T$ and $C C R$ genes activation seem to rely on higher cryptogein concentrations. Furthermore, it appears that the early phase of the calcium response is mainly responsible for their transcriptional response. Such differential responsiveness to calcium response would allow the plant to selectively activate genes of the phenylpropanoid pathway.

To explain these results one might consider that different calcium stores involved in the generation of the cryptogein-induced calcium signature (Garcia-Brügger et al. 2006, Kadota et al. 2004, Lecourieux et al. 2002) contribute differently to the subsequent biological responses. However, computer simulations of our two-component model rather suggest the existence of two different calcium decoding modules, with low and high affinity for calcium, associated with the main calcium peak and the sustained phase (plateau) respectively, and displaying either an inhibiting or an activating effect.

This model is also supported by the specific effect of calmodulin inhibitor W13 on the transcriptional response to low cryptogein concentrations only, which suggests the involvement of calmodulins or calmodulin-like proteins in the transduction process. This effect could be simulated with our model by increasing the value of the "apparent" affinity coefficient of the "activation" component (Fig.10). One may thus hypothesize that W13 inhibits calcium-binding proteins (such as CaMs, CMLs or potentially other EF-hand 
1 
1 The authors thank Sabine Grat for her technical assistance in cell culture maintenance and

2 Nathalie Ladouce for her help in RT-qPCR analysis. Raoul Ranjeva thanks the Miller Institute

3 for Basic Research (UC Berkeley) for supporting him with a Miller Visiting Professorship.

4 Nicolas Amelot thanks the Association pour la Recherche sur les Nicotianae for financial

5 support. This work was supported by a grant from the Agence Nationale pour la Recherche

6 (ANR-06-BLAN-370) and by the Centre National de la Recherche Scientifique.

\section{REFERENCES}

Allen G.J., Chu S.P., Harrington C.L., Schumacher K., Hoffmann T., Tang Y.Y., Grill E. \& Schroeder J.I. (2001a) A defined range of guard cell calcium oscillation parameters encodes stomatal movements. Nature, 411, 1053-1057.

Allen G.J. \& Schroeder J.I. (2001b) Combining genetics and cell biology to crack the code of plant cell calcium signaling. Science STKE, 2001, RE13.

Binet M.N., Humbert C., Lecourieux D., Vantard M. \& Pugin A. (2001) Disruption of microtubular cytoskeleton induced by cryptogein, an elicitor of hypersensitive response in tobacco cells. Plant Physiology, 125, 564-572.

Bolwell G.P., Robbins M.P. \& Dixon R.A. (1985) Metabolic changes in elicitor-treated bean cells. Enzymic responses associated with rapid changes in cell wall components. European Journal of Biochemistry, 148, 571-578.

Bonnet P., Bourdon E., Ponchet M., Blein J.-P. \& Ricci P. (1996) Acquired resistance triggered by elicitins in tobacco and other plants. European Journal of Plant Pathology, 102, 181-192.

Bourque S., Binet M.N., Ponchet M., Pugin A. \& Lebrun-Garcia A. (1999) Characterization of the cryptogein binding sites on plant plasma membranes. Journal of Biological Chemistry, 274, 34699-34705. 
1 Boursiac Y. \& Harper J.F. (2007) The origin and function of calmodulin regulated $\mathrm{Ca}^{2+}$ pumps in plants. Journal of Bioenergetics and Biomembranes, 39, 409-414.

Dagher R., Briere C., Feve M., Zeniou M., Pigault C., Mazars C., Chneiweiss H., Ranjeva R., Kilhoffer M.C. \& Haiech J. (2008) Calcium fingerprints induced by Calmodulin interactors in eukaryotic cells. Biochimica Biophysica Acta, 1793, 1068-1077.

Dixon R.A. \& Paiva N.L. (1995) Stress-induced phenylpropanoid metabolism. The Plant Cell, 7, 1085-1097.

Garcia-Brügger A., Lamotte O., Vandelle E., Bourque S., Lecourieux D., Poinssot B., Wendehenne D. \& Pugin A. (2006) Early signaling events induced by elicitors of plant defenses. Molecular Plant Microbe Interactions, 19, 711-724.

Hano C., Addi M., Bensaddek L., Crônier D., Baltora-Rosset S., Doussot J., Maury S., Mesnard F., Chabbert B., Hawkins S., Lainé E. \& Lamblin F. (2006) Differential accumulation of monolignol-derived compounds in elicited flax ( Linum usitatissimum) cell suspension cultures. Planta, 223, 975-989.

Hetherington A.M. \& Brownlee C. (2004) The generation of $\mathrm{Ca}^{2+}$ signals in plants. Annual Review of Plant Biology, 55, 401-427.

Israelsson M., Siegel R.S., Young J., Hashimoto M., Iba K. \& Schroeder J.I. (2006) Guard cell $\mathrm{ABA}$ and $\mathrm{CO} 2$ signaling network updates and $\mathrm{Ca}^{2+}$ sensor priming hypothesis. Current Opinion in Plant Biology, 9, 654-663.

Kadota Y., Goh T., Tomatsu H., Tamauchi R., Higashi K., Muto S. \& Kuchitsu K. (2004) Cryptogein-induced initial events in tobacco BY-2 cells: pharmacological characterization of molecular relationship among cytosolic $\mathrm{Ca}^{2+}$ transients, anion efflux and production of reactive oxygen species. Plant and Cell Physiology, 45, 160170. 
1 Kaplan B., Davydov O., Knight H., Galon Y., Marc R. Knight, Fluhr R. \& Fromm H. (2006) Rapid transcriptome changes induced by cytosolic $\mathrm{Ca}^{2+}$ transients reveal ABRErelated sequences as $\mathrm{Ca}^{2+}$-responsive cis rlements in Arabidopsis. The Plant Cell, 18, $2733-2748$

Kauss H., Franke R., Krause K., Conrath U., Jeblick W., Grimmig B. \& Matern U. (1993) Conditioning of parsley (Petroselinum crispum L.) suspension cells increases elicitorinduced incorporation of cell wall phenolics. Plant Physiology, 102, 459-466.

Keller H., Bonnet P., Galiana E., Pruvot L., Friedrich L., Ryals J. \& Ricci P. (1996a) Salicylic acid mediates elicitin-induced systemic acquired resistance, but not necrosis in tobacco. Molecular Plant-Microbe Interactions, 9, 696-703.

Keller H., Hohlfeld H., Wray V., Hahlbrock K., Scheel D. \& Strack D. (1996b) Changes in the accumulation of soluble and cell wall-bound phenolics in elicitor-treated cell suspension cultures and fungus-infected leaves of Solanum tuberosum. Phytochemistry, 42, 389-396.

Kim J. \& Kim H.Y. (2006) Functional analysis of a calcium-binding transcription factor involved in plant salt stress signaling. FEBS Letters, 580, 5251-5256.

Kim M.C., Chung W.S., Yun D.J. \& Cho M.J. (2009) Calcium and Calmodulin-Mediated Regulation of Gene Expression in Plants. Molecular Plant, 2, 13-21.

Kudla J., Batistic O. \& Hashimoto K. (2010) Calcium Signals: The Lead Currency of Plant Information Processing. The Plant Cell, in press.

Lecourieux D., Mazars C., Pauly N., Ranjeva R. \& Pugin A. (2002) Analysis and effects of cytosolic free calcium increases in response to elicitors in Nicotiana plumbaginifolia cells. The Plant Cell, 14, 2627-2641.

Lecourieux D., Ranjeva R. \& Pugin A. (2006) Calcium in plant defence-signalling pathways. New Phytologist, 171, 249-269. 
Article Amelot.docx

1 McAinsh M.R. \& Pittman J.K. (2009) Shaping the calcium signature. New Phytologist, 181,

2

3

4

5

6

7

8 275-294.

Miwa H., Sun J., Oldroyd G.E. \& Downie J.A. (2006) Analysis of calcium spiking using a cameleon calcium sensor reveals that nodulation gene expression is regulated by calcium spike number and the developmental status of the cell. Plant Journal, 48, 883894.

Moscatiello R., Mariani P., Sanders D. \& Maathuis F.J.M. (2006) Transcriptional analysis of calcium-dependent and calcium-independent signalling pathways induced by oligogalacturonides. Journal of Experimental Botany, 57, 2847-2865.

Nair R.B., Bastress K.L., Ruegger M.O., Denault J.W. \& Chapple C. (2004) The Arabidopsis thaliana REDUCED EPIDERMAL FLUORESCENCE1 gene encodes an aldehyde dehydrogenase involved in ferulic acid and sinapic acid biosynthesis. The Plant Cell, 16, 544-554.

Pauly N., Knight M.R., Thuleau P., Graziana A., Muto S., Ranjeva R. \& Mazars C. (2001) The nucleus together with the cytosol generates patterns of specific cellular calcium signatures in tobacco suspension culture cells. Cell Calcium, 30, 413-421.

Pauly N., Knight M.R., Thuleau P., Van der Luit A.H., Moreau M., Trewavas A.J., Ranjeva R. \& Mazars C. (2000) Control of free calcium in plant cell nuclei. Nature, 405, 754755.

Pfaffl M.W. (2001) A new mathematical model for relative quantification in real-time RTPCR. Nucleic Acids Research, 29, e45.

Podstolski A., Havkin-Frenkel D., Malinowski J., Blount J.W., Kourteva G. \& Dixon R.A. (2002) Unusual 4-hydroxybenzaldehyde synthase activity from tissue cultures of the vanilla orchid Vanilla planifolia. Phytochemistry, 61, 611-620. 
Article Amelot.docx

1 Pontier D., Godiard L., Marco Y. \& Roby D. (1994) hsr203J, a tobacco gene whose activation is rapid, highly localized and specific for incompatible plant/pathogen interactions. Plant Journal, 5, 507-521.

Qudeimat E., Faltusz A.M., Wheeler G., Lang D., Brownlee C., Reski R. \& Frank W. (2008) A PIIB-type $\mathrm{Ca}^{2+}$-ATPase is essential for stress adaptation in Physcomitrella patens. Proceedings of the National Academy of Sciences of the United States of America, 105, 19555-19560.

R Development Core Team (2009) R: A language and environment for statistical computing. R Foundation for Statistical Computing, Vienna, Austria.

Schroeder J.I., Allen G.J., Hugouvieux V., Kwak J.M. \& Waner D. (2001) Guard Cell Signal Transduction. Annual Review of Plant Physiology and Plant Molecular Biology, 52, 627-658.

Shinya T., Galis I., Narisawa T., Sasaki M., Fukuda H., Matsuoka H., Saito M. \& Matsuoka K. (2007) Comprehensive analysis of glucan elicitor-regulated gene expression in tobacco BY-2 cells reveals a novel MYB transcription factor involved in the regulation of phenylpropanoid metabolism. Plant and Cell Physiology, $\mathbf{4 8 .}$

Sircar D. \& Mitra A. (2008) Evidence for p-hydroxybenzoate formation involving enzymatic phenylpropanoid side-chain cleavage in hairy roots of Daucus carota. Journal of Plant Physiology, 165, 407-414.

Sudha G. \& Ravishankar G. (2002) Involvement and interaction of various signaling compounds on the plant metabolic events during defense response, resistance to stress factors, formation of secondary metabolites and their molecular aspects. Plant Cell, Tissue and Organ Culture, 71, 181-212.

Suty L., Blein J., Ricci P. \& Pugin A. (1995) Early changes in gene expression in tobacco cells elicited with cryptogein. Molecular Plant Microbe Interactions, 8, 644-651. 
Article Amelot.docx

1 Suzuki A., Yano A., Nishiuchi T., Nakano T., Kodama H., Yamaguchi K. \& Shinshi H. (2003) Comprehensive analysis of early response genes to two different microbial elicitors in tobacco cells. Plant Science, 173, 291-301.

Tadross M.R., Dick I.E. \& Yue D.T. (2008) Mechanism of local and global $\mathrm{Ca}^{2+}$ sensing by calmodulin in complex with a $\mathrm{Ca}^{2+}$ channel. Cell, 133, 1228-1240.

Takahashi K., Isobe M., Knight M.R., Trewavas A.J. \& Muto S. (1997) Hypoosmotic shock induces increases in cytosolic $\mathrm{Ca}^{2+}$ in tobacco suspension-culture cells. Plant Physiology, 113, 587-594.

Ward E.R., Uknes S.J., Williams S.C., Dincher S.S., Wiederhold D.L., Alexander D.C., AhlGoy P., Metraux J.P. \& Ryals J.A. (1991) Coordinate gene activity in response to agents that induce systemic acquired resistance. The Plant Cell, 3, 1085-1094.

Ward J.M., Pei Z.-M. \& Schroeder J.I. (1995) Roles of ion channels in initiation of signal transduction in higher plants. The Plant Cell, 7, 833-844.

Weckwerth W. (2003) Metabolomics in systems biology. Annual Review of Plant Biology, 54, 669-689.

White P.J. \& Broadley M.R. (2003) Calcium in plants. Annals of Botany, 92, 487-511.

Xiong T.C., Bourque S., Lecourieux D., Amelot N., Grat S., Briere C., Mazars C., Pugin A. \& Ranjeva R. (2007) Calcium signaling in plant cell organelles delimited by a double membrane. Biochimica and Biophysica Acta, 1763, 1209-1215. 
Article Amelot.docx

\section{Table 1}

2 Cryptogein effect on the accumulation of insoluble phenolic compounds in tobacco BY-2

3 cells. For each compound, ratio between treated versus control cells was calculated based on

4 their relative amounts measured by MS/MS. Data are means and standard-errors from 4

5 independent experiments. Paired-t-test was used for statistical comparisons between amounts

6 (Log transformed).
Phenolic compound
Ratio (mean \pm SE)
$P$ value

\begin{tabular}{lll}
\hline$p$-coumaric acid & $3.3 \pm 1.0$ & 0.04
\end{tabular}

\begin{tabular}{lcc}
\hline ferulic acid & $1.9 \pm 0.3$ & 0.05 \\
\hline 5-hydroxyferulic acid & $184 \pm 112$ & 0.005 \\
\hline 4-hydrobenzaldehyde & $1.8 \pm 0.3$ & 0.06 \\
\hline
\end{tabular}

7

8

9 
Article Amelot.docx

\section{Figures legends}

2 Figure 1. Biosynthetic routes for phenolic compounds adapted from the model proposed by

3 Nair et al. (2004) for A. thaliana. Encircled compounds accumulate in tobacco BY-2 cell

4

walls in response to cryptogein. Light grey arrows indicate routes that are unlikely to occur in planta. Dotted arrow indicates a hypothetic route for the biosynthesis of 5-hydroxyferulate (see results section). PAL, phenylalanine ammonia-lyase; $\mathrm{C} 4 \mathrm{H}$, cinnamate 4-hydroxylase; 4CL, 4-coumarate-CoA ligase; $\mathrm{C} 3 \mathrm{H}, p$-coumarate 3-hydroxylase; HCT, hydroxycinnamoyl CoA:quinate/shikimate hydroxycinnamoyltransferase; CCoAOMT, caffeoyl-CoA 3-Omethyltransferase; COMT caffeic acid/5-hydroxyferulic acid $O$-methyltransferase; F5H, ferulate 5-hydroxylase; CCR, cinnamoyl CoA reductase; CAD, cinnamyl alcohol dehydrogenase. REF1, Reduced Epidermal Fluorescence1.

Figure 2. Cryptogein-induced calcium signatures in tobacco BY-2 cells. (a) Time-course of calcium variation in BY-2 cells induced either by $\mathrm{H}_{2} \mathrm{O}$ (trace) or cryptogein (1 $\mu \mathrm{M}$, bullets) (data from one representative experiment). (b) Dose-dependence of ( $)$ peak value and plateau value. (means \pm s.e. of 3 independent experiments) .

Figure 3. Effects of cryptogein on transcript accumulation of phenylpropanoid genes in tobacco BY-2 cells. (a) Relative transcript levels of genes of phenylpropanoid in cells challenged for $4 \mathrm{~h}$ with $0.1 \mu \mathrm{M}$ cryptogein in the absence (grey) or presence (black) of $1 \mathrm{mM}$ $\mathrm{La}^{3+}$. (b) Time-course of $P A L$ (white), HCT (grey), and CCoAOMT (black) transcript accumulation induced by $0.1 \mu \mathrm{M}$ cryptogein. (c) Dose-dependence of transcript levels of $P A L$ (white), HCT (grey) and CCOAOMT (black) on a 4-hour cryptogein treatment. Transcript levels assessed by RT qPCR are expressed as mean \pm s.e. $(n=3)$ of transcript ratios relative to control cells $\left(\mathrm{H}_{2} \mathrm{O}\right.$ treatment). 
1 Figure 4. Principal Component Analysis (PCA). Analysis of transcription ratio data plus

2 calcium-peak and calcium-plateau values from dose-response experiments. Symbols $10 \mathrm{nM}$ to $1 \mu \mathrm{M}$ represent the cryptogein concentration used in experiments. Cry+la $=$ Co-treatment with $\mathrm{La}^{3+}$. Planes defined by the first two principal components are displayed. Figure 5. Time course of relative enzymatic activities of PAL and CCOAOMT. Activities were measured in total protein extracts from cells challenged with $0.1 \mu \mathrm{M}$ cryptogein: PAL (white bars) and CCoAOMT (black bars). Traces: relative transcript levels of CCoAOMT (closed symbols) and PAL (open symbols). Inset: Effect of $1 \mathrm{mM} \mathrm{La}^{3+}$ on PAL and CCoAOMT activities measured after a 4-hour treatment. Enzyme activities are expressed relative to control cells $\left(\mathrm{H}_{2} \mathrm{O}\right.$ treatment). Means \pm s.e. $(n=3)$.

Figure 6. Distribution of radioactivity in tobacco BY-2 cell suspensions incubated for 4 hours with $\left[{ }^{14} \mathrm{C}(\mathrm{U})\right]$-cinnamic acid. At $\mathrm{t}=0$ hour, cells were treated with water (control, white bar), $0.1 \mu \mathrm{M}$ cryptogein (black bar), or $0.1 \mu \mathrm{M}$ cryptogein $+1 \mathrm{mM} \mathrm{La}^{3+}$ (grey bar). Relative radioactivity is expressed as the ratio of the activity measured in one compartment over the total radioactivity added to the cell suspension. Means \pm s.e. $(n=3)$.

Figure 7. Effect of inhibiting calcium influx on cryptogein-induced calcium variations (a) and transcript accumulation (b) in tobacco BY-2 cells. $1 \mathrm{mM} \mathrm{La}^{3+}$ was added at $\mathrm{t}=0$ (black line and black bars) or $\mathrm{t}=10$ minutes (grey line and grey bars) after treating cells with $0.5 \mu \mathrm{M}$ cryptogein. In (b) data are expressed as the percentage of inhibition of the transcript accumulation induced by cryptogein alone (means \pm s.e. of 3 experiments).

Figure 8. Effects of calmodulin inhibitors W12 and W13 on the cryptogein-response. (a) Effects of W13 preincubation on the cryoptogein-induced calcium signature. Bullets: $50 \mathrm{nM}$ cryptogein, empty bullets: $50 \mu \mathrm{M} \mathrm{W} 13+50 \mathrm{nM}$ cryptogein, square: $250 \mathrm{nM}$ cryptogein, empty square: $50 \mu \mathrm{M} \mathrm{W} 13+250 \mathrm{nM}$ cryptogein (means \pm s.e. of 2 replicates). (b) Effects of W12 
1 (negative control) and W13 preincubation on cryptogein-induced CCOAOMT transcript

2 accumulation. Control (white bar), W12 (grey bar) and W13 (black bar). Inhibitors $(50 \mu \mathrm{M})$

3 were added to cells 10 minutes before cryptogein. Data are representative of two independent

4 experiments.

$5 \quad$ Figure 9. Proposed model for regulation of cryptogein-induced transcriptional response by

6 calcium.

7 Figure 10. Fits of the two-component model described in Fig. 9 to experimental data. (a)

8 Dose-response curves for transcript accumulation of $P A L$ (circle), $H C T$ (triangle) and

9 CCOAOMT (square) induced by a 4-hour treatment with cryptogein. (b) Effect of anti-CaM

10 compounds on CCOAOMT transcript accumulation induced by cryptogein: control (+), W-12

11 pre-treatment (x), W-13 pre-treatment (*). Experimental data (symbols) and theoretical

12 curves (lines). Parameter values are given in Supporting Information S7. 
Article Amelot.docx

\section{Supporting Information:}

2 Table S1: primers and amplicons sizes.

3 Figure S2: Comparison between lanthanum chloride and EGTA pre-treatments on cryptogein-

4 induced phenylpropanoid genes.

5 Figure S3: Effects of a cycloheximide pre-treatment on cryptogein-induced transcript accumulation of phenylpropanoid genes.

Figure S4: Effect of cryptogein on transcript accumulation of genes coding for isoforms of $P A L, 4 C L$ and CCOAOMT.

9 Figure S5: Cytosolic calcium responses to calmodulin inhibitors in tobacco BY-2 cells.

Figure S6: Assessment of cryptogein-induced cell death in tobacco BY-2 cells.

Figure S7: Model formulation. 


\section{Figure 1}

Phenylalanine

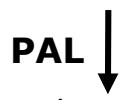

cinnamate

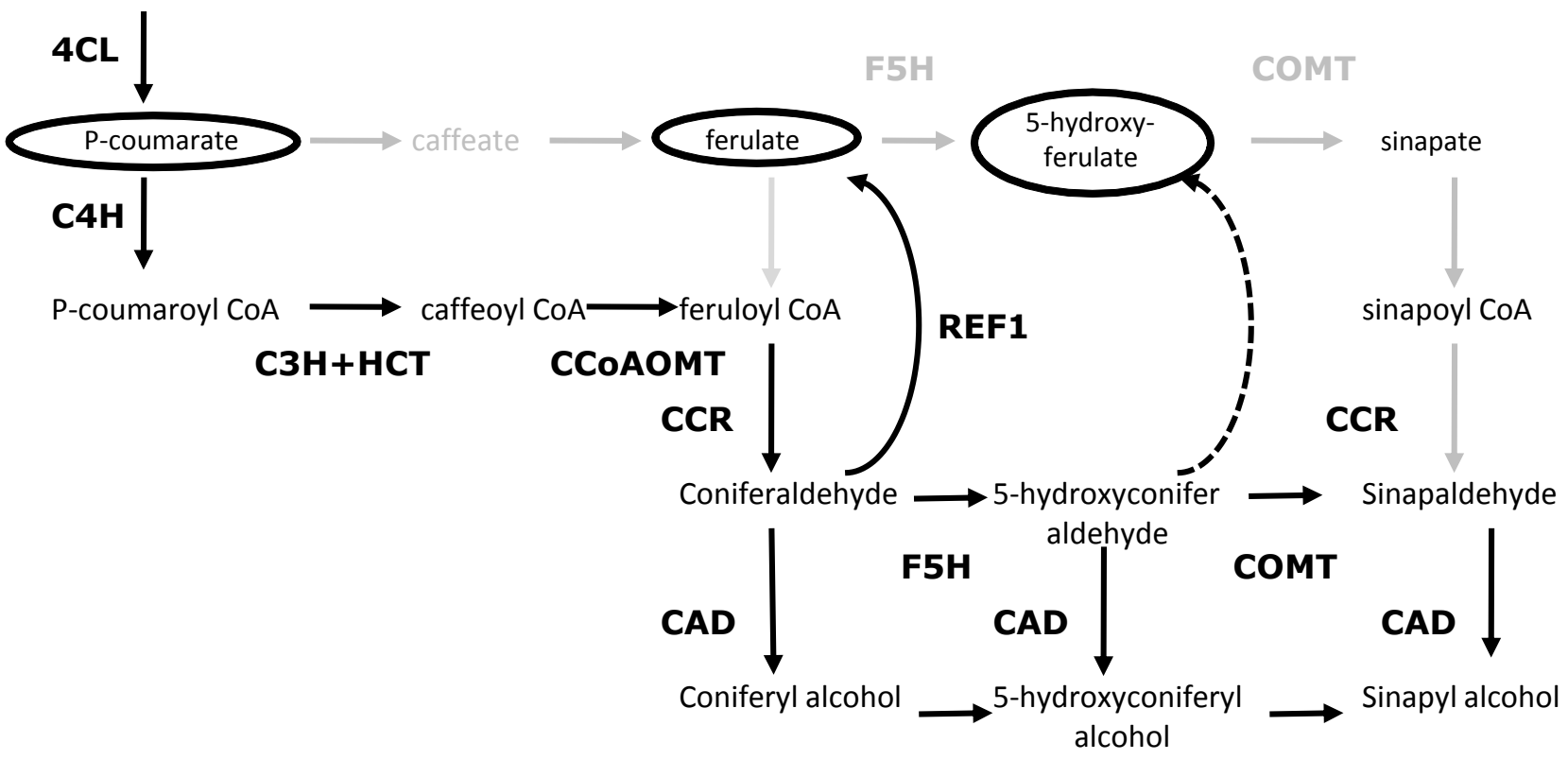


Figure 2
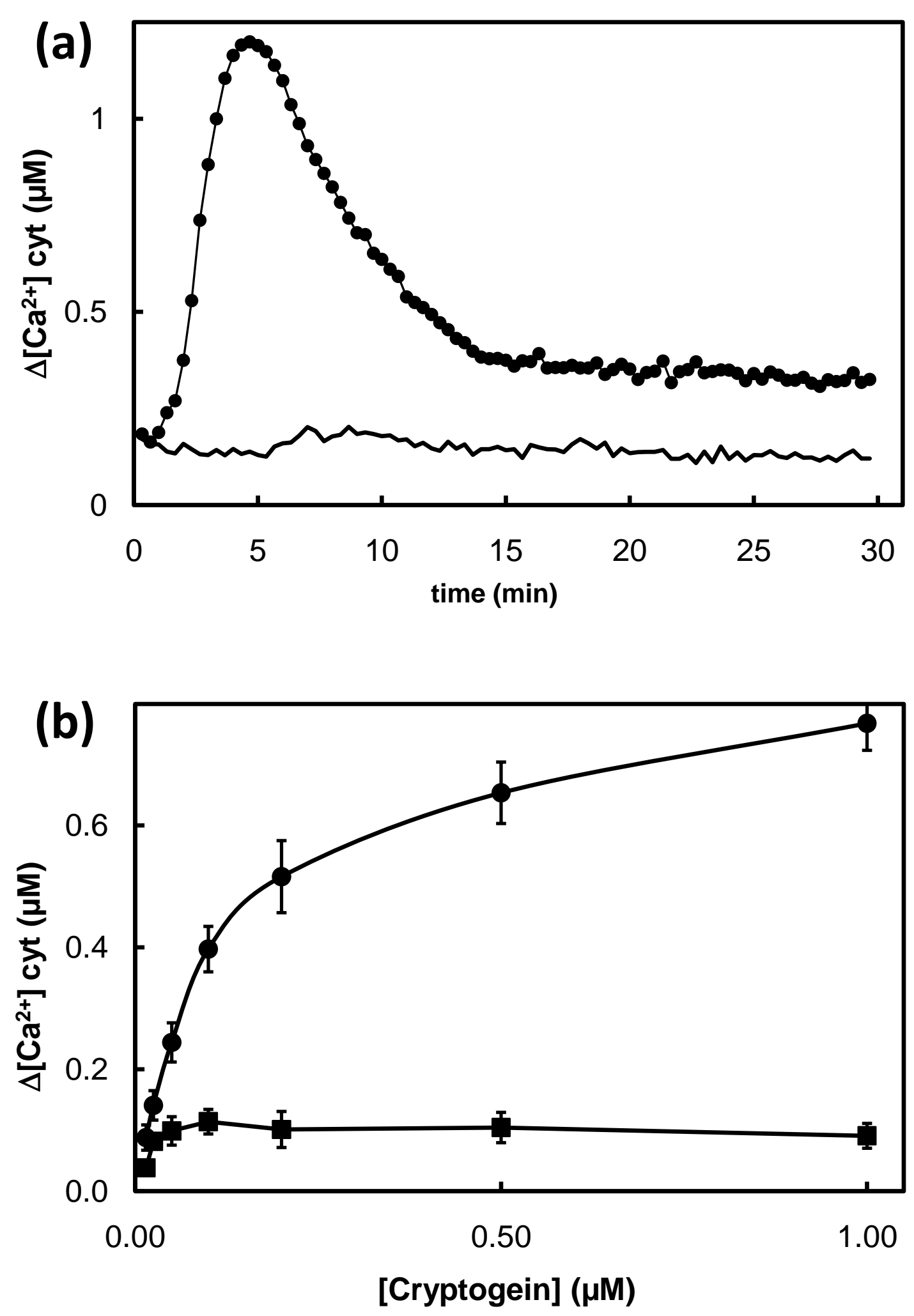
Figure 3
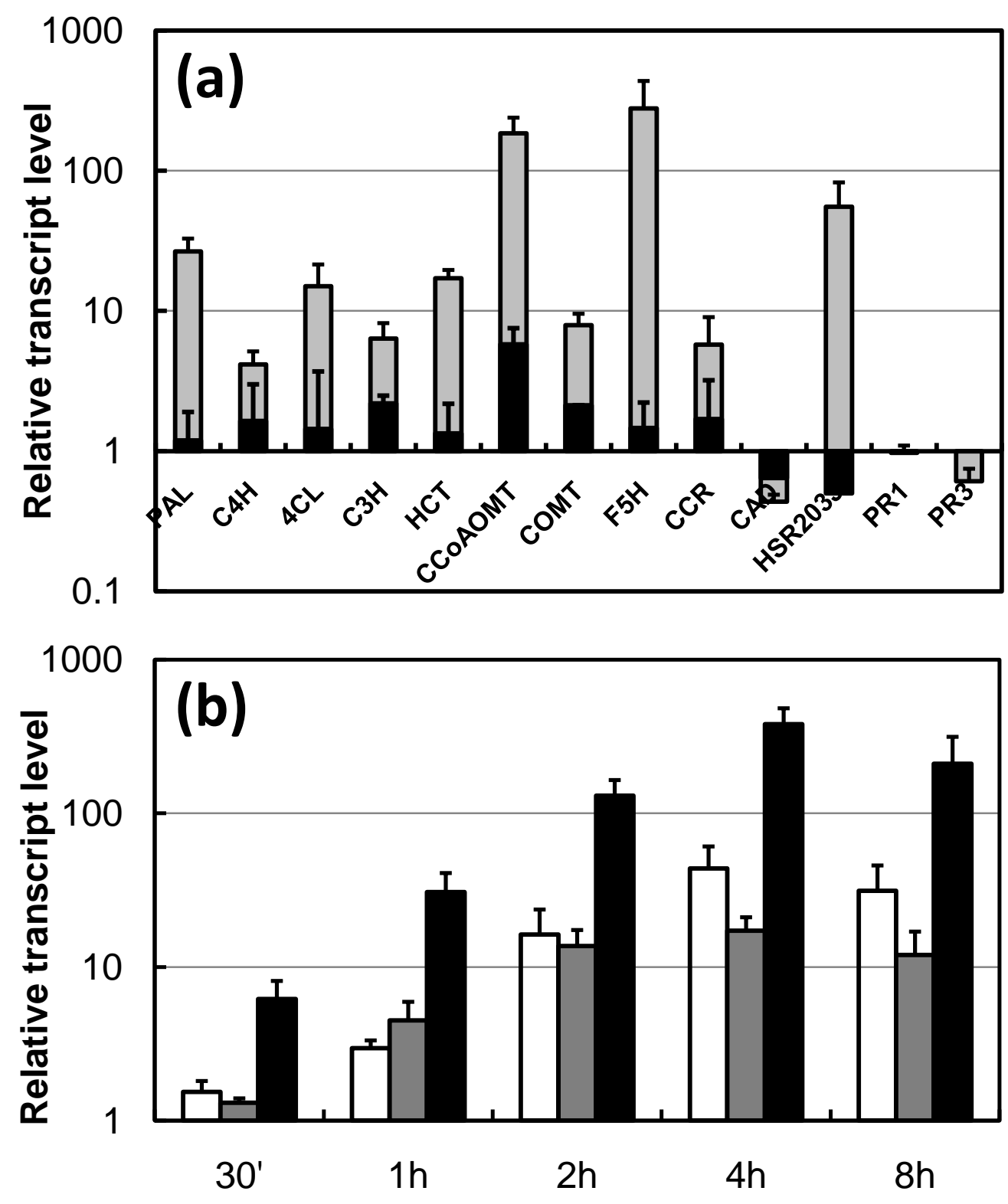

Time after elicitation

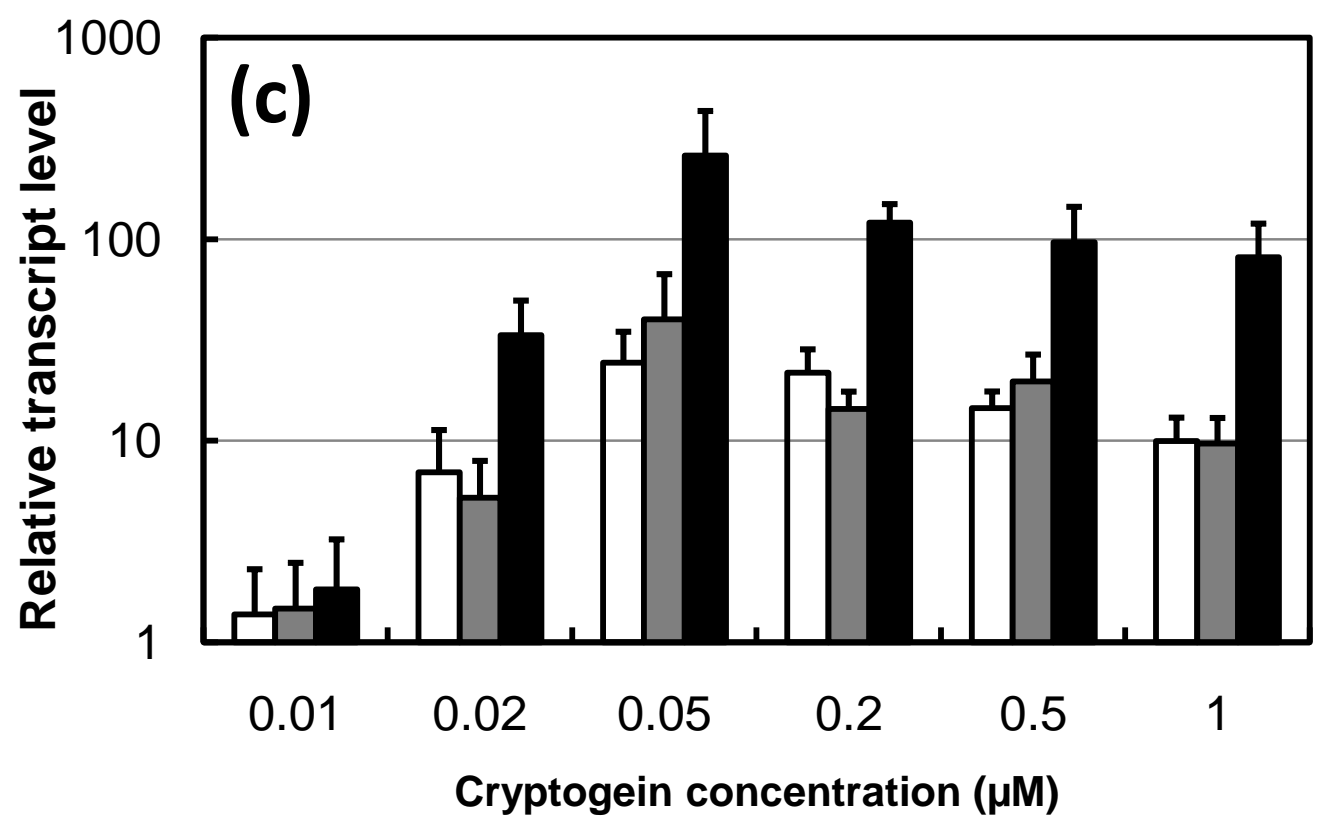


Figure 4

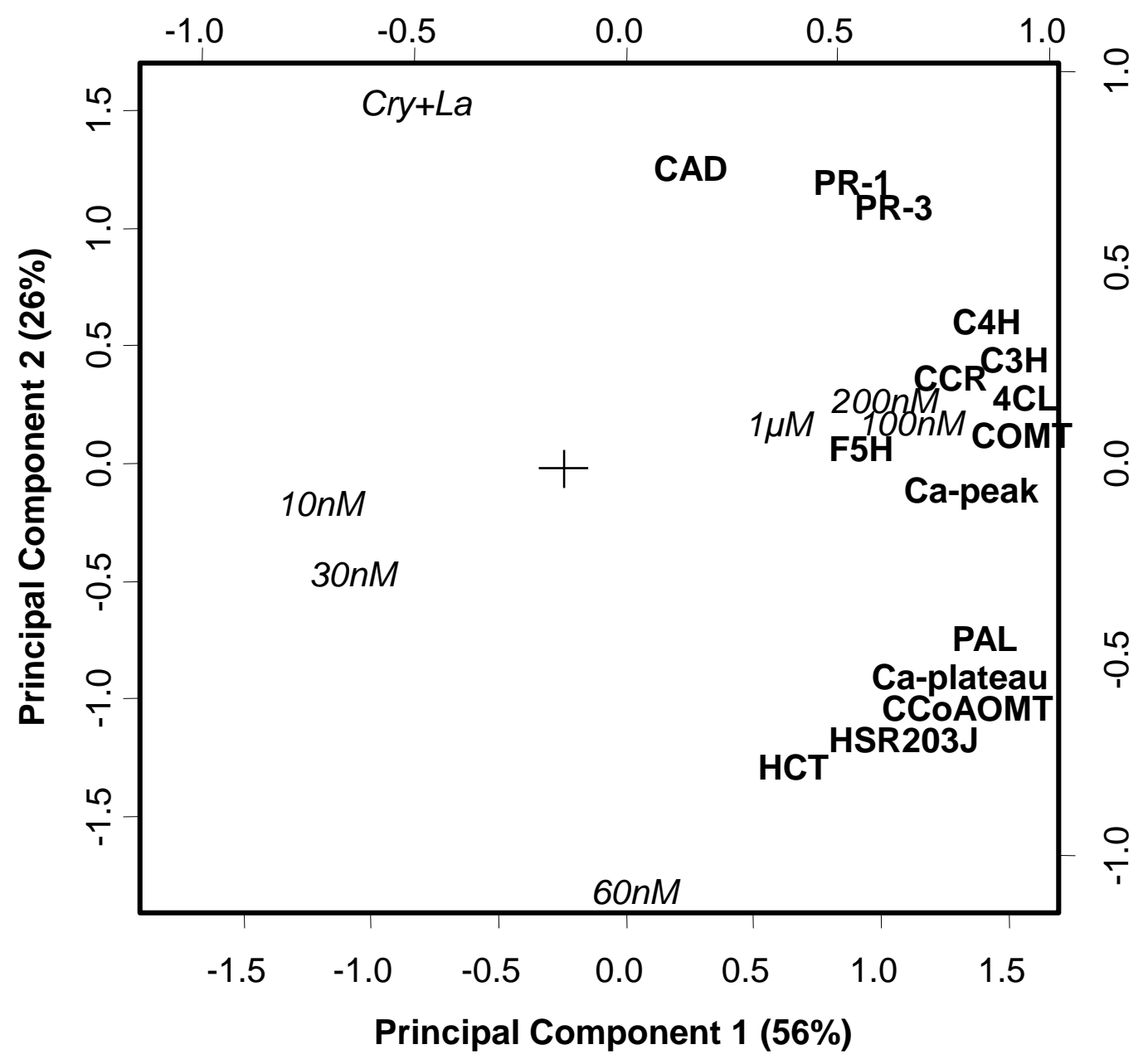


Figure 5

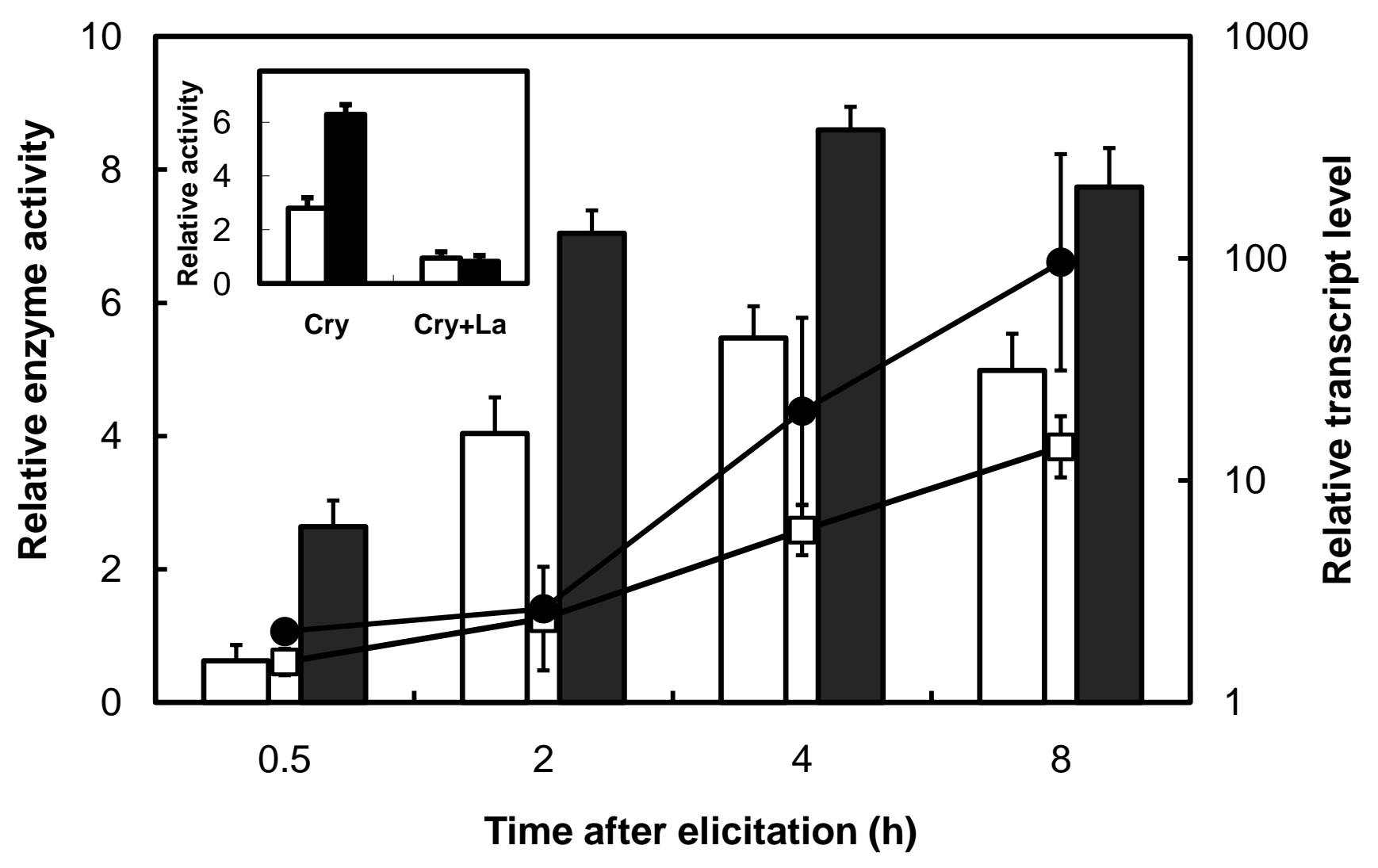




\section{Figure 6}

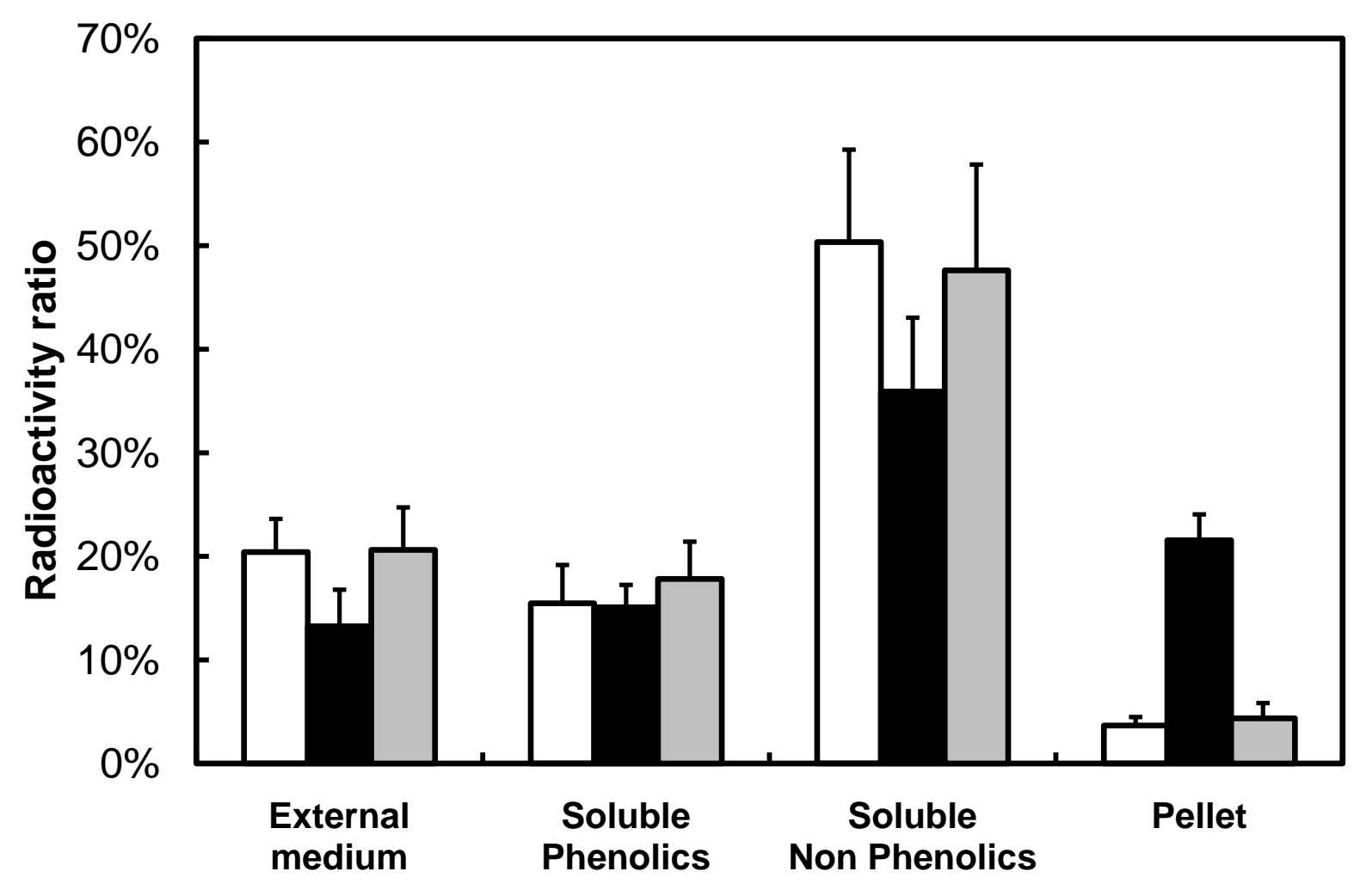


Figure 7
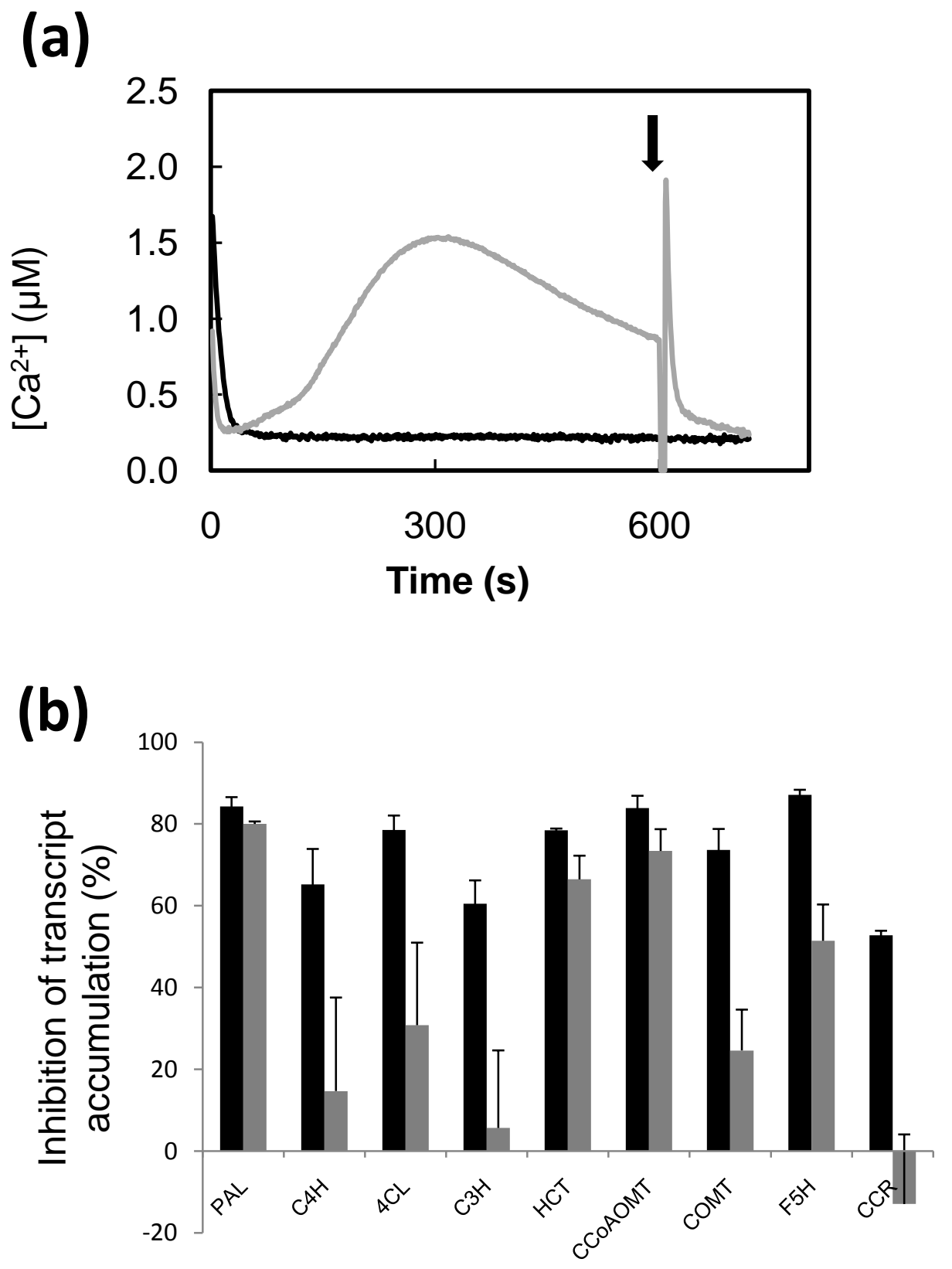


\section{Figure 8}
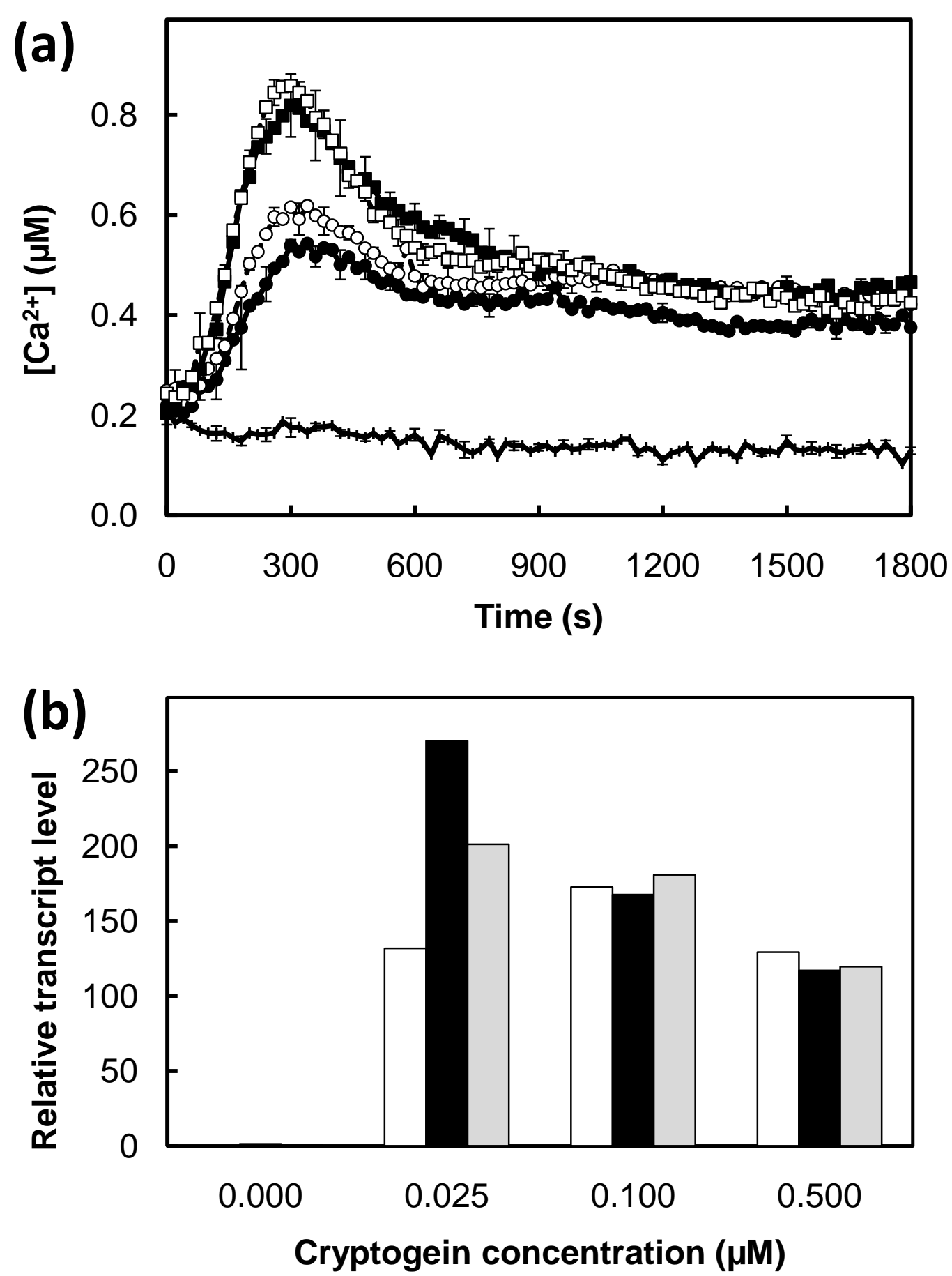
Figure 9

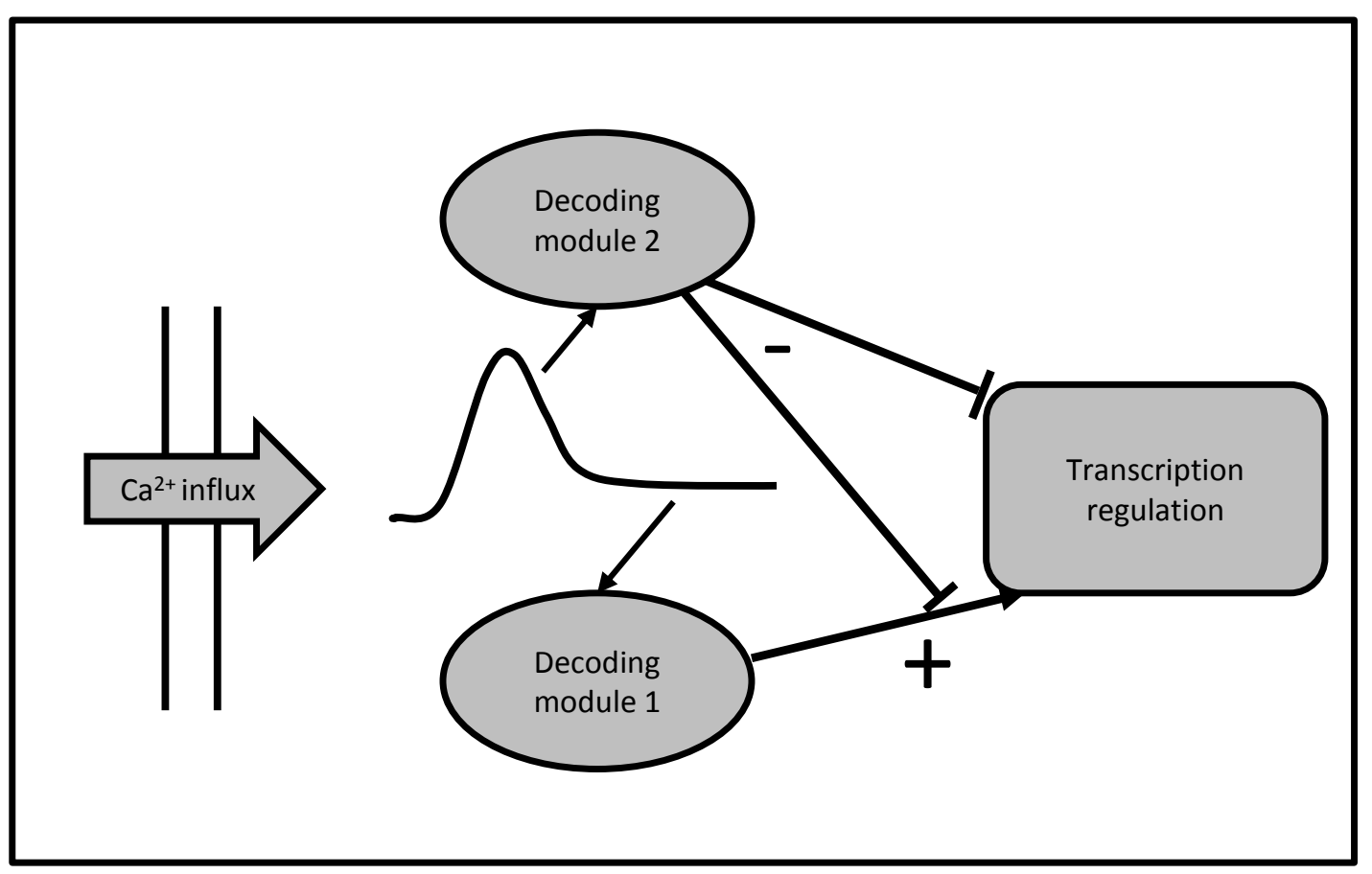


Figure 10
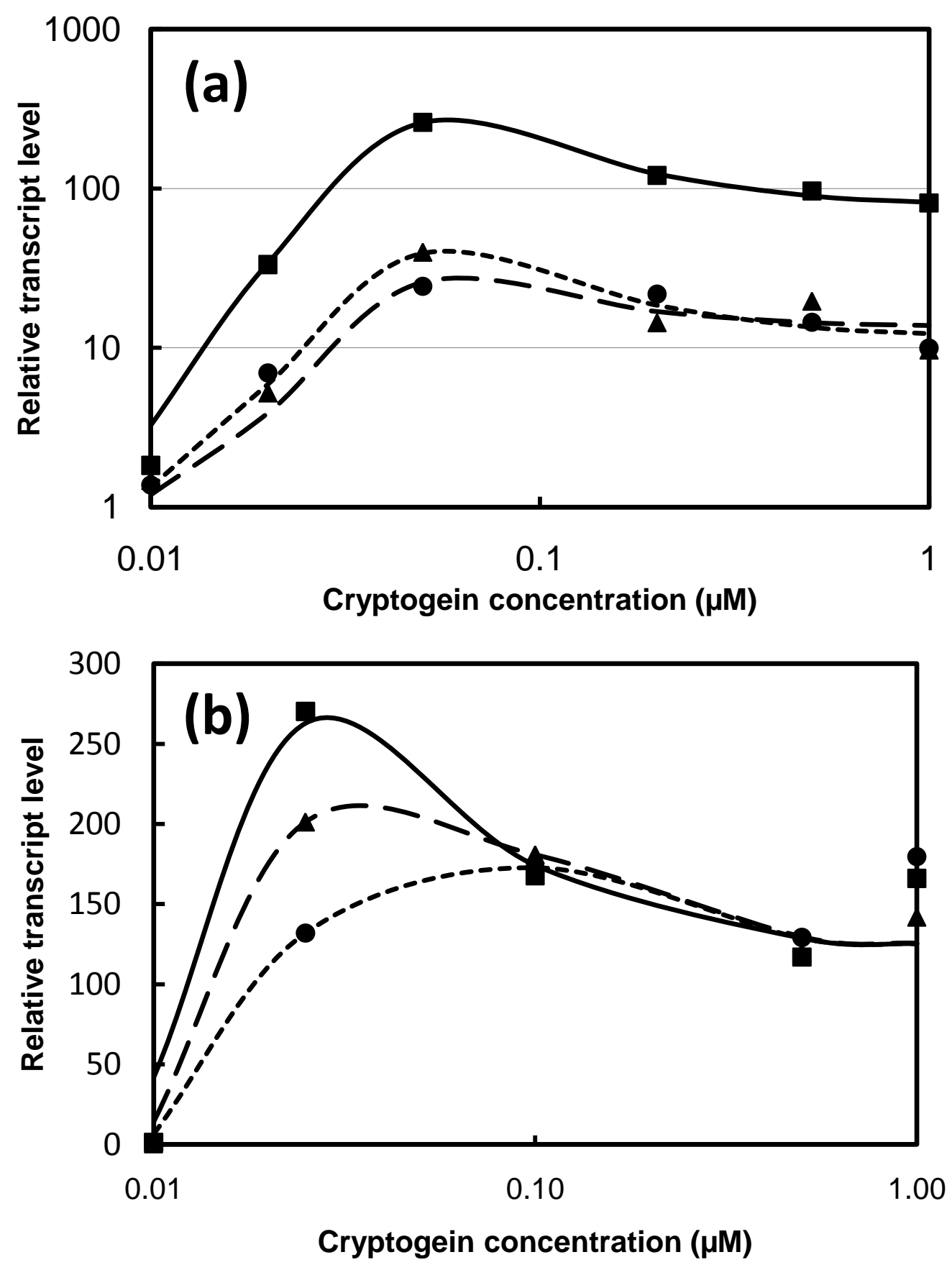
Table S1: Primers and amplicon sizes:

\begin{tabular}{|c|c|c|c|}
\hline Gene & Amplicon size & upper 5' & lower 5 \\
\hline $18 S r R N A$ & $171 b p$ & cgcgctacactgatgtattc & gtacaaagggcagggacgta \\
\hline$P A L$ & $94 b p$ & gacaaagtgttcacagcaatg & aaacagatwggaagaggagca \\
\hline$P A L \mathrm{~A}$ & $228 b p$ & cctcgtcgaccacgccttgc & taattcagctccaagttctc \\
\hline$P A L \mathrm{~B}$ & $242 b p$ & acacattgccacattcagca & caccattgggaccaacagcc \\
\hline $\mathrm{C} 4 \mathrm{H}$ & $124 b p$ & tcaacacaatggtggaatgc & actttgggacgtttggttca \\
\hline $4 C L$ & $89 b p$ & cttctcaaccatcccaacatt & ctaacaacaaaagccactgga \\
\hline $4 C L 1$ & $178 b p$ & ttcctggagttaatacagaag & gggaatttggttctcacagcg \\
\hline $4 C L 2$ & 179bp & tttcttggagttgatacaacg & ggaaatttggctcgaacagta \\
\hline COMT & $132 b p$ & cctgcaaatgggaaggtgat & cagtcctttctttgcetcct \\
\hline $\mathrm{C} 3 \mathrm{H}$ & $142 b p$ & tggctgaggtgatcaagaac & tatgggaggaaggggaagtc \\
\hline$H C T$ & $127 \mathrm{bp}$ & ggctgccaatccatgatgct & gcaacagattgactgccatca \\
\hline CCOAOMT & $96 b p$ & acaccctatggaatggatca & ccttgttgagttccaatacga \\
\hline CСOAOMT 1 & $89 \mathrm{bp}$ & aatttgccagctacctgttggt & ttggttgccacaaatagacgat \\
\hline CCOAOMT 2 & $92 \mathrm{bp}$ & gaactattgtccatttgtggca & acgaatgatacagaacagggga \\
\hline CСOAOMT 3 & $130 b p$ & tttacagggctagttcatggca & ggtaacatcgacaatgcaacct \\
\hline CCOAOMT 4 & $102 b p$ & cattggctgctgattctaga & aaatcctccattgcctgtaa \\
\hline CCOAOMT 5 & $113 b p$ & acgtatgatttcatatttgtggat & caatccttggatcaacggctagg \\
\hline ССоАОМТ6 & $121 \mathrm{bp}$ & cacatatgatttcattttcgtgg & caattctgggatcagctgccaaa \\
\hline$F 5 H$ & $100 \mathrm{bp}$ & agcccggacaaggaagat & cccatccaagccaaggta \\
\hline$C C R$ & $99 \mathrm{bp}$ & gacttctgcaaaaacaccaa & caccaaatcgactcctttt \\
\hline
\end{tabular}




\section{S2. Comparison between lanthanum chloride and EGTA pre-treatments on cryptogein-induced phenylpropanoid genes expression in tobacco BY-2 cells.}
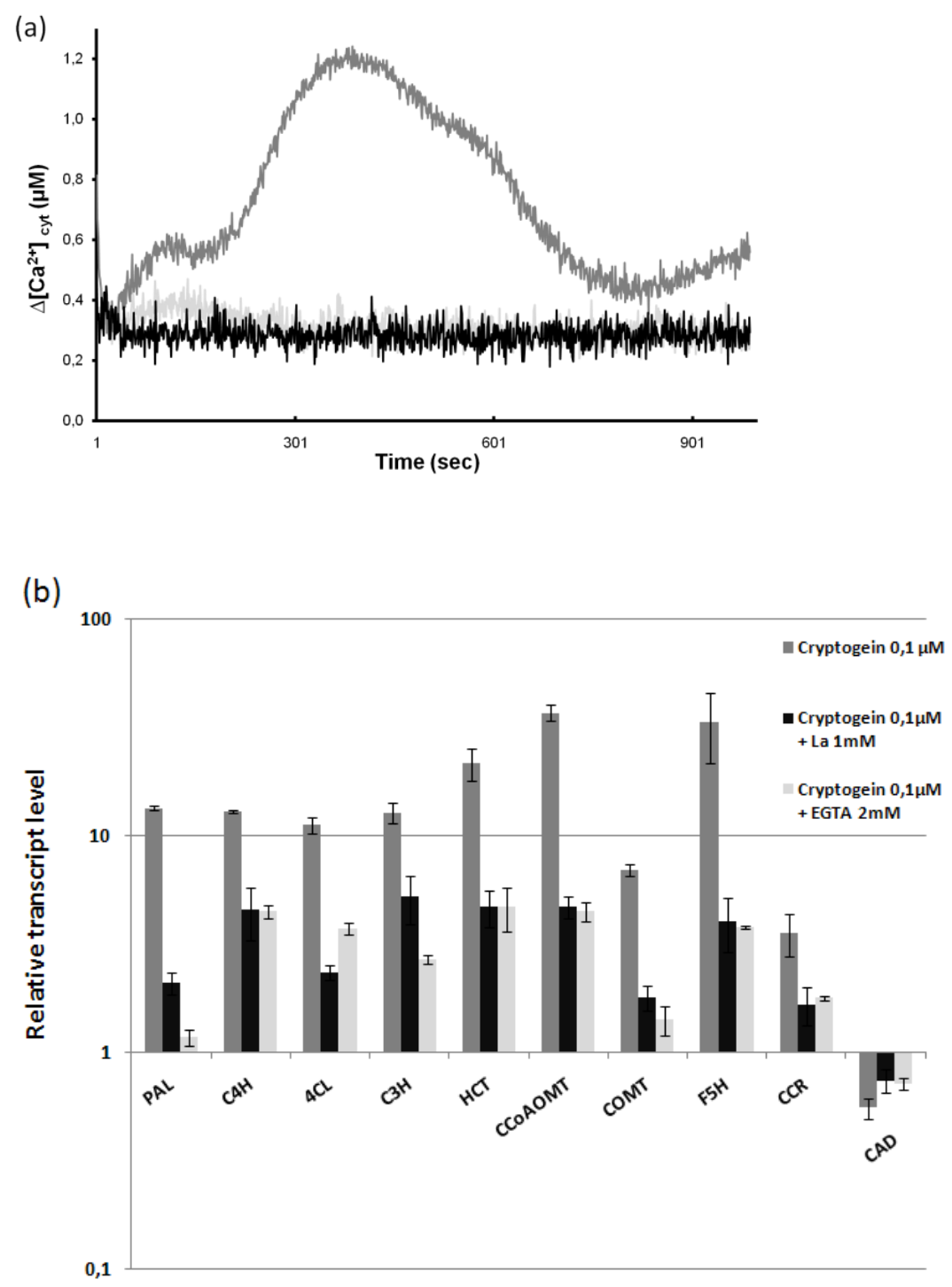

Figure S2. Comparison between lanthanum chloride and EGTA pre-treatments on cryptogeininduced phenylpropanoid genes expression in tobacco BY-2 cells.

(a) Time course of cytosolic calcium variation in response to $0.1 \mu \mathrm{M}$ cryptogein in the absence (dark grey trace) or presence of either $1 \mathrm{mM} \mathrm{La}^{3+}$ (black trace) or 2mM EGTA (light grey trace). Data show one representative experiment out of three. (b) Relative transcript levels assessed by RT-qPCR in cells treated for 3 hours with $0.1 \mu \mathrm{M}$ cryptogein in the absence (dark grey bars) or presence of either $1 \mathrm{mM} \mathrm{La}^{3+}$ (black bars) or $2 \mathrm{mM}$ EGTA (light grey bars).

Transcript levels are expressed as means $\pm \mathrm{SE}(\mathrm{n}=3)$ of transcript ratios relative to control cells $\left(\mathrm{H}_{2} \mathrm{O}\right.$ treatment). 


\section{S3. Effects of a cycloheximide pre-treatment on cryptogein-induced phenylpropanoid genes in BY-2 tobacco cells}

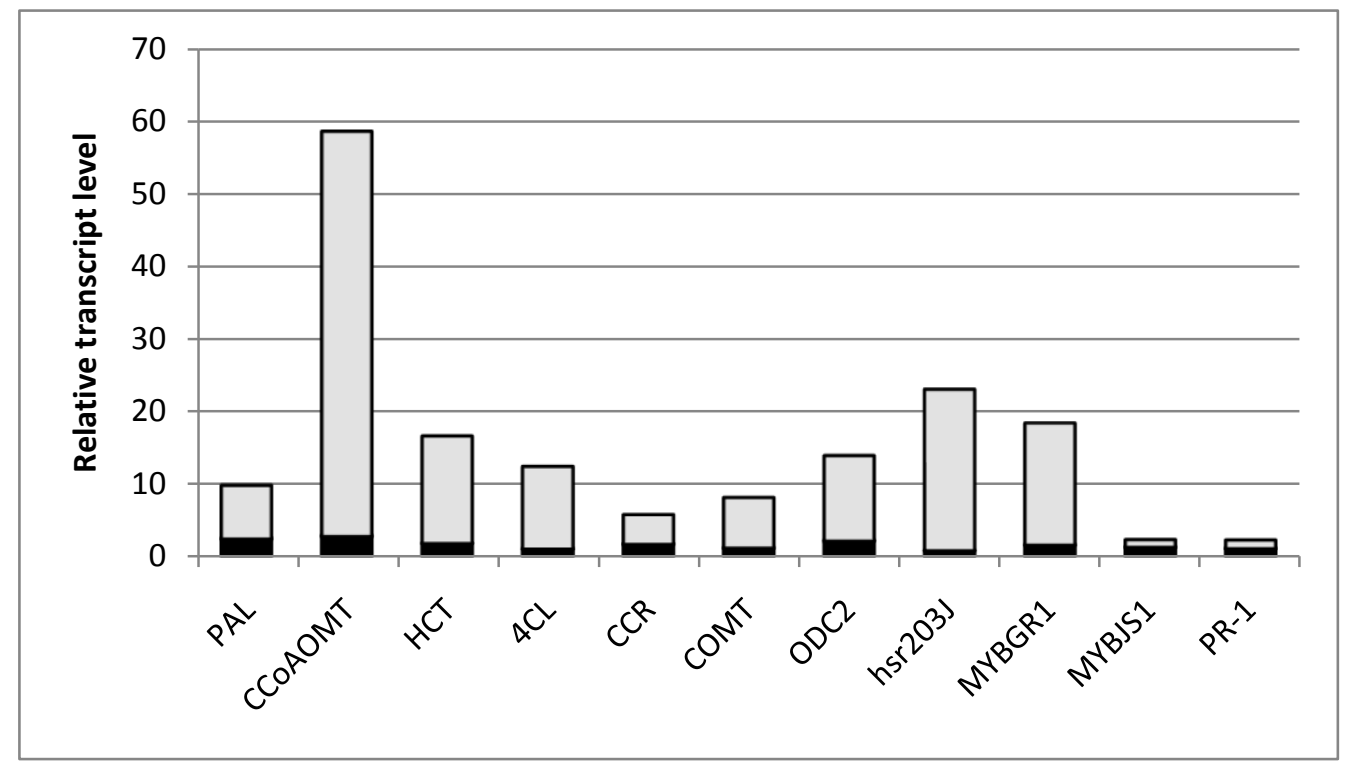

Figure S3. Effect of a cycloheximide pre-treatment on the cryptogein-induced accumulation of phenylpropanoid gene transcripts. Transcript levels were assessed by RT-qPCR in tobacco BY-2 cells treated for 3 hours with $0.1 \mu \mathrm{M}$ cryptogein. Relative transcript levels are ratios of transcript numbers assessed in treated cells to those of cycloheximide only-treated cells.

Black bars: cells pre-incubated during 30-minutes with $50 \mu \mathrm{M}$ cycloheximide before cryptogein treatment. Grey bars: control (no pre-treatment) cells (data from one experiment). 
S4. Effect of cryptogein on expression of genes coding for isoforms of PAL, 4CL and CCoAOMT

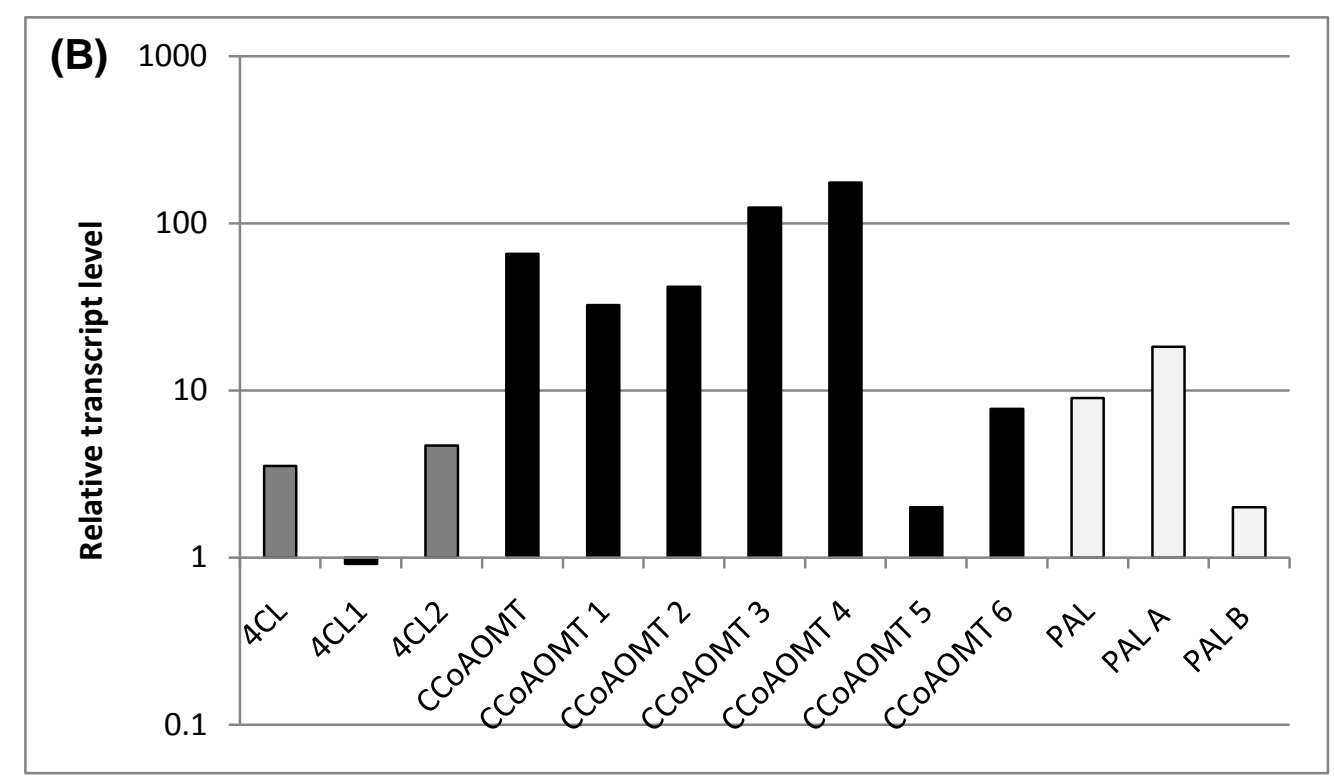

Figure S4. Relative transcript levels of genes coding for PAL, 4CL and CCoAOMT isoforms. Transcript levels were assessed by RT-qPCR in tobacco BY-2 cells treated for 3 hours with $0.1 \mu \mathrm{M}$ cryptogein. Relative transcript levels are ratios of transcript levels assessed in treated cells versus transcript levels obtained in control $\left(\mathrm{H}_{2} \mathrm{O}\right.$ treated) cells (data from one experiment). 
S5. Cytosolic calcium responses to calmodulin inhibitors in tobacco BY-2 cells
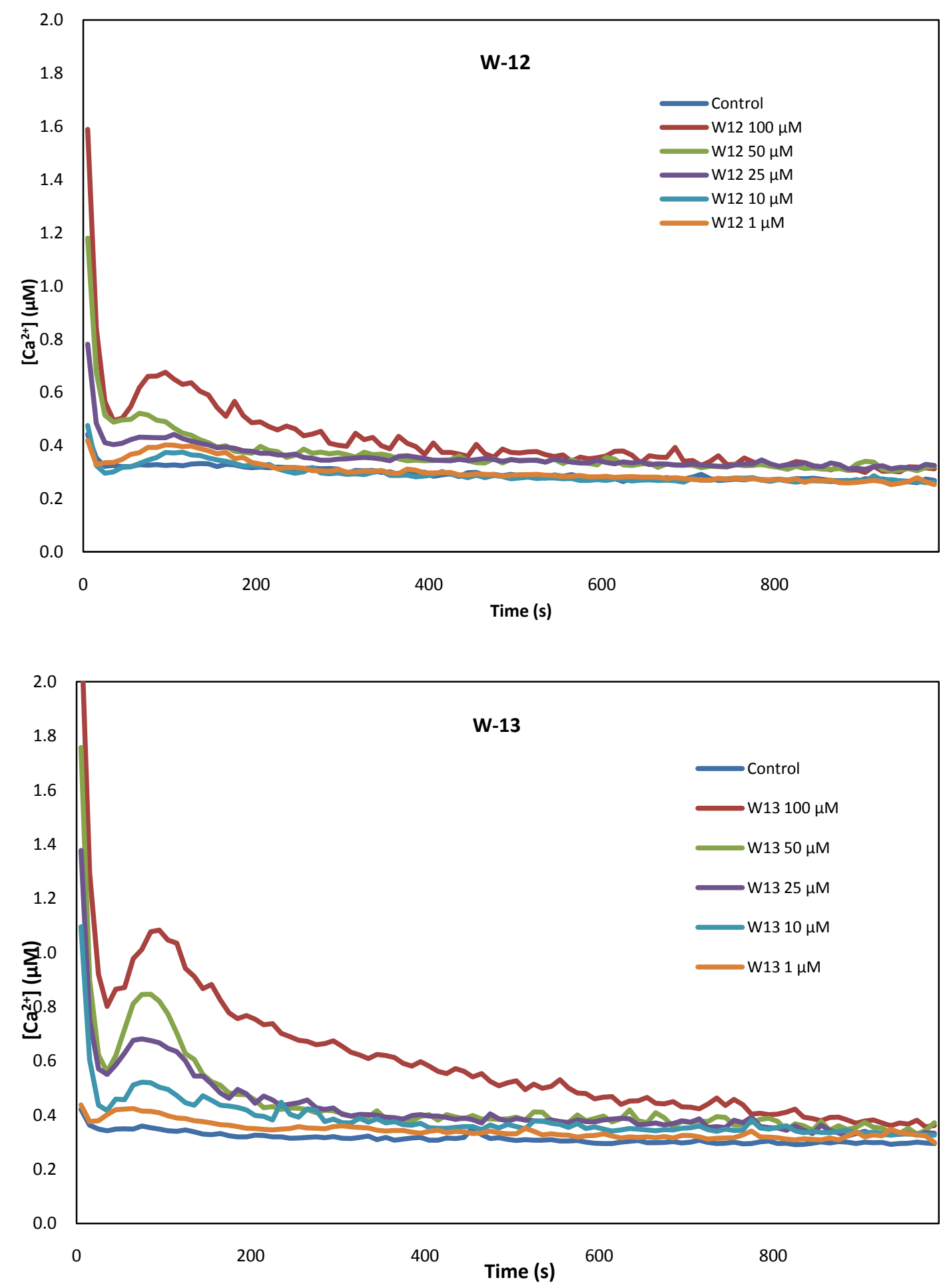

Figure S5. Cytosolic calcium variations induced in tobacco BY-2 cells by calmodulin interactors: W12 (low affinity, $\mathrm{Kd}=250 \mu \mathrm{M}$ ) and W13 (high affinity, $\mathrm{Kd}=50 \mu \mathrm{M}$ ). 
S6. Assessment of cryptogein-induced cell death in tobacco BY-2 cells.

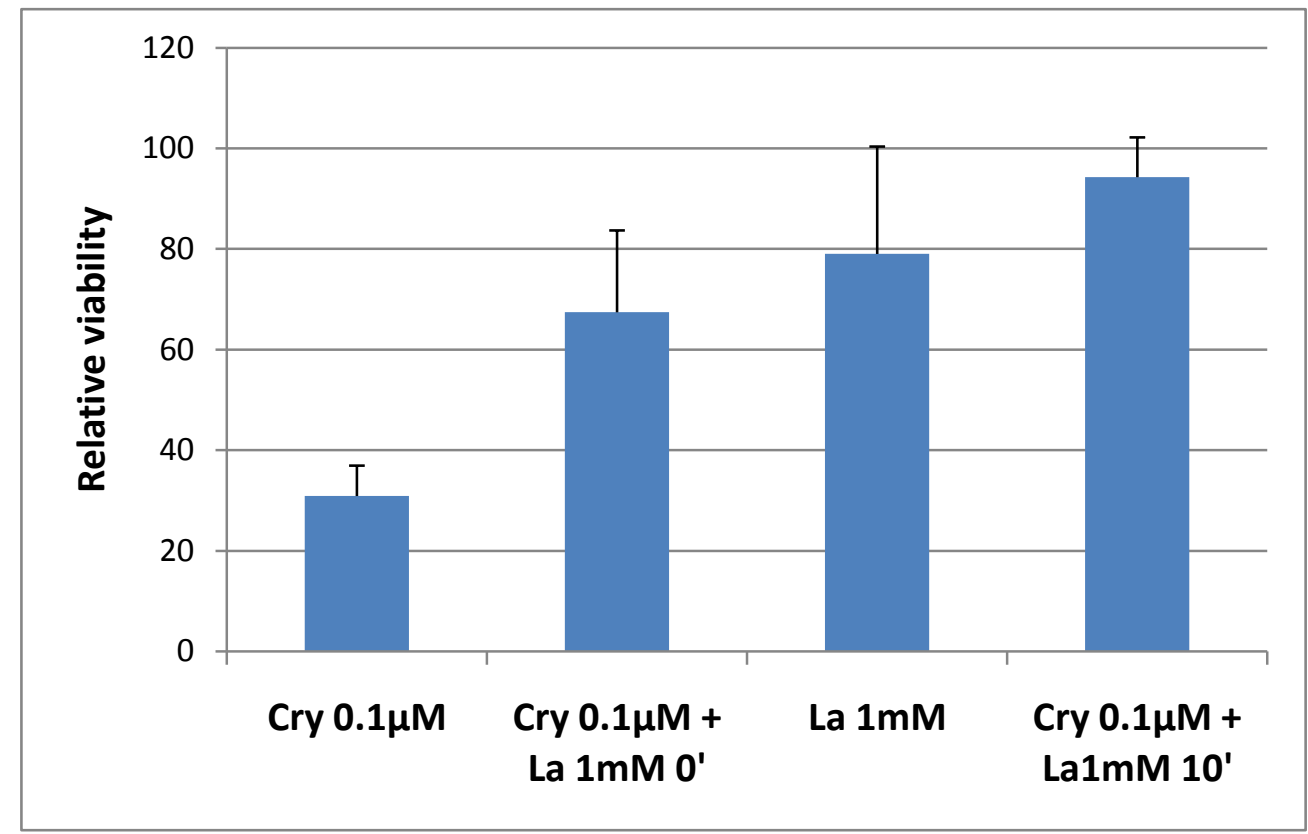

Figure S6. Effect of a 24-hour treatment with cryptogein and/or $1 \mathrm{mM} \mathrm{La}^{3+}$ on the viability of tobacco BY-2 suspension cultured cells (relative viability of treated cells to that of control cells (data from one experiment with three replicates). 


\section{S7. Model formulation}

The model used to describe the relationship between cryptogein concentration " $\mathrm{C}$ " and transcript ratio "R" (measured 4 hours after treatment) was inspired from enzymatic kinetic laws for one ligand and two binding sites (Adair-Klotz model) and Hill phenomenological equation. Here the ligand is cryptogein, the observable variable is the transcript ratio, and the binding sites correspond by analogy to the two putative decoding modules. Thus the equilibrium reads as follows:

$$
R=\frac{1+S 1(K 1 \cdot C)^{n 1}+S 2\left(K 1 \cdot K 2 \cdot C^{2}\right)^{n 2}}{1+(K 1 \cdot C)^{n 1}+\left(K 1 \cdot K 2 \cdot C^{2}\right)^{n 2}}
$$

Where $\mathrm{K} 1, \mathrm{~S} 1$, and $\mathrm{n} 1$ are the association constant, the maximum response and the Hill coefficient for component 1(respectively K2, S2, and $\mathrm{n} 2$ for component 2). For a given condition Ki values and Hill coefficients were supposed to be the same for all genes, while coefficients S1 and S2 were gene dependent.

Estimated values of the coefficients for three genes (data from Fig. 10a):

$\mathrm{K} 1=23.3 \mu \mathrm{M}^{-1} ; \mathrm{K} 2=24.9 \mu \mathrm{M}^{-1} ; \mathrm{n} 1=3.9 ; \mathrm{n} 2=2.7$

\begin{tabular}{|l|l|l|l|}
\hline & PAL & HCT & CCoAOMT \\
\hline S1 & 58.2 & 101.9 & 678 \\
\hline S2 & 13.5 & 77.6 & 11.6 \\
\hline
\end{tabular}

Estimated values of the coefficients for CCoAOMT (data from Fig. 10b):

$\mathrm{S} 1=411.2 ; \mathrm{S} 2=123.3 ; \mathrm{n} 1=3.9 ; \mathrm{n} 2=2.7 ; \mathrm{K} 2=30.5$

\begin{tabular}{|l|l|l|l|}
\hline & Cryptogein & $\begin{array}{l}\text { W12 }+ \\
\text { Cryptogein }\end{array}$ & $\begin{array}{l}\text { W13 }+ \\
\text { Cryptogein }\end{array}$ \\
\hline $\mathrm{K} 1\left(\mu \mathrm{M}^{-1}\right)$ & 33.1 & 41.4 & 52.8 \\
\hline
\end{tabular}

